Article

\title{
Periselectivity in the Aza-Diels-Alder Reaction of 1-Azadienes with $\alpha$-Oxoketenes: A Combined Experimental and Theoretical Study
}

\author{
Marc Presset ${ }^{\dagger}$, Michel Rajzmann, Guillaume Dauvergne, Jean Rodriguez * \\ and Yoann Coquerel *(D)
}

Aix Marseille Université, CNRS, Centrale Marseille, ISM2, 13397 Marseille, France; presset@icmpe.cnrs.fr (M.P.); michel.rajzmann@univ-amu.fr (M.R.); guillaume.dauvergne@univ-amu.fr (G.D.)

* Correspondence: jean.rodriguez@univ-amu.fr (J.R.); yoann.coquerel@univ-amu.fr (Y.C.)

† Present address: Université Paris-Est Créteil, CNRS, ICMPE, UMR 7182, 2 rue Henri Dunant, F-94320 Thiais, France.

Received: 25 September 2020; Accepted: 15 October 2020; Published: 20 October 2020

check for updates

\begin{abstract}
Inversions in the periselectivity of formal aza-Diels-Alder cycloadditions between $\alpha$-oxoketenes generated by a thermally-induced Wolff rearrangement and 1-azadienes were observed experimentally as a function of the $\alpha$-oxoketene and the 1 -azadiene, as well as the reaction temperature and time. Some unexpected inversion in the diastereoselectivity was observed, too. These variations in selectivities were fully rationalized by computational modeling using density functional theory (DFT) methods.
\end{abstract}

Keywords: hetero-Diels-Alder; ketenes; imines; periselectivity; density functional theory

\section{Introduction}

$\alpha$-Oxoketenes [1-6] were first employed in organic synthesis in 1902 with the pioneering work of Ludwig Wolff on 2-diazo-1,3-dicarbonyl compounds [7]. Since, $\alpha$-oxoketenes have revealed as versatile chemical intermediates for synthetic applications, ranging from the preparation of simple $\beta$-oxocarbonyl derivatives [8] to the total synthesis of complex natural products $[4,5]$. However, and with few exceptions $[9,10], \alpha$-oxoketenes are not stable species because of their propensity to react with a number of chemicals, including themselves [11], at significant rates at ambient temperature; thus, they must be generated in situ immediately before use. The most common and practical methods for the generation of $\alpha$-oxoketenes are the thermal decomposition of dioxinones with concomitant extrusion of acetone [12], and the thermal or photochemical Wolff rearrangement of 2-diazo-1,3-dicarbonyl compounds extruding nitrogen gas [13,14]. $\alpha$-Oxoketenes 1 are electrophilic species that most commonly react with imines through formal aza-Diels-Alder cycloadditions involving the $\alpha$-oxoketenes as $4 \pi$ reaction partners (1-oxadienes) and the imines as the $2 \pi$ reaction partners to give 1,3-oxazin-4-ones of type 4 (Scheme 1) [1-6,15]. However, when $\alpha, \beta$-unsaturated imines 2 are employed, another formal aza-Diels-Alder process becomes possible, involving the $\alpha, \beta$-unsaturated imines as $4 \pi$ reaction partners (1-azadienes) and the $\alpha$-oxoketenes as the $2 \pi$ reaction partners to give hydropyridin-2-ones of type 3 [16]. Periselectivity, the selectivity in formation of the pericyclic products, in the formal aza-Diels-Alder cycloadditions between $\alpha$-oxoketenes and some electron rich 2-azadienes was recently examined and found to be dependent on kinetic and thermodynamic factors, as well as the nature of the $\alpha$-oxoketene employed [11]. For the present study, the periselectivity in the reactions of $\alpha$-oxoketenes with $\alpha, \beta$-unsaturated imines as prototypical 1-azadienes was further investigated and rationalized by a combination of experimental and computational studies. 


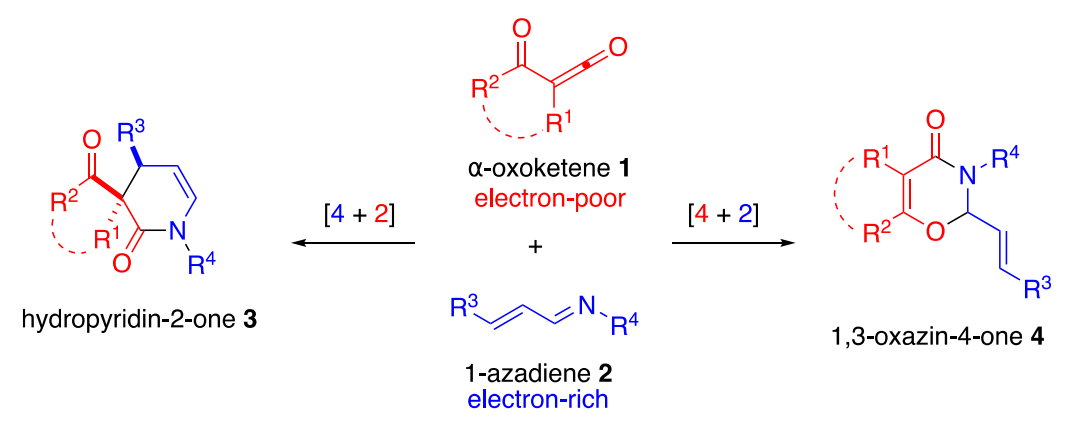

Scheme 1. Periselectivity in the formal aza-Diels-Alder cycloadditions of $\alpha$-oxoketenes with $\alpha, \beta$-unsaturated imines.

\section{Results and Discussion}

We previously reported the formal aza-Diels-Alder cycloaddition between the $\alpha, \beta$-unsaturated imine $2 \mathbf{a}$ and the five-membered cyclic $\alpha$-oxoketene $1 \mathbf{a}$ derived from the thermal Wolff rearrangement of 2-diazodimedone to give the spiro hydropyridin-2-one 3a in $24 \%$ yield after $15 \mathrm{~min}$ of reaction at $160^{\circ} \mathrm{C}$ (Scheme 2a) [16]. Re-examination of the temperature dependence of the reaction outcome revealed that the other pericyclic product, namely the 1,3-oxazin-4-one $4 \mathbf{a}$, is actually formed when the reaction is performed at $140{ }^{\circ} \mathrm{C}$ with a 2:1 3a/4a ratio after $15 \mathrm{~min}$, which allowed isolating $3 \mathbf{a}$ in $38 \%$ yield and $\mathbf{4 a}$ in $21 \%$ yield. A similar reaction conducted at $150{ }^{\circ} \mathrm{C}$ for $30 \mathrm{~min}$ afforded only $3 \mathrm{a}$ in $22 \%$ isolated yield (3a/4a $>25: 1)$. Stimulated by these observations, some complementary experiments were performed to further illustrate the possible change in periselectivity in the aza-Diels-Alder cycloadditions between $\alpha$-oxoketenes and 1-azadienes as a function of the reaction temperature (Scheme $2 \mathrm{~b}-\mathrm{e}$ ). For instance, the reaction between $\alpha$-oxoketene $\mathbf{1} \mathbf{a}$ and the enantiopure 1 -azadiene $\mathbf{2} \mathbf{b}$ derived from $(-)$-perillaldehyde and allylamine at $140{ }^{\circ} \mathrm{C}$ for $15 \mathrm{~min}$ afforded the corresponding diastereomeric 1,3-oxazin-4-ones $4 \mathbf{b}$ in $59 \%(\mathrm{dr}=1: 1)$ while it was previously shown to afford the spiro hydropyridin-2-one $3 \mathbf{b}$ after $15 \mathrm{~min}$ at $200{ }^{\circ} \mathrm{C}$ [16]. Similarly, it was found earlier that spiro hydropyridin-2-one $3 \mathrm{c}$ could be obtained efficiently from the 2-methyl-1-azadiene $2 \mathrm{c}$ from a reaction at $160{ }^{\circ} \mathrm{C}$ [16], while a mixture of the two possible pericyclic products $3 \mathrm{c}$ and $4 \mathrm{c}$ was obtained at $140{ }^{\circ} \mathrm{C}$. Some degree of thermodynamic control of the reaction could be demonstrated experimentally in this case: heating a toluene solution of $4 \mathrm{c}$ at $160{ }^{\circ} \mathrm{C}$ for $15 \mathrm{~min}$ produced $25 \%$ of $3 \mathrm{c}$ together with $20 \%$ of 2-methylcinnamaldehyde and unidentified products. Surprisingly, the reactions of $\alpha$-oxoketene 1a with the 3-chloro 1-azadiene $\mathbf{2 d}$, led exclusively to the corresponding 1,3-oxazin-4-one $4 \mathbf{d}$ with no detectable amount of $3 \mathbf{d}$, at $140{ }^{\circ} \mathrm{C}$ or $200{ }^{\circ} \mathrm{C}$. The influence of the nature (phenyl vs. methyl) of the substituent at position 4 of the 1 -azadiene on periselectivity was briefly evaluated through the reaction of $\alpha$-oxoketene $\mathbf{1 a}$ with 1 -azadienes $\mathbf{2 e}$ $(\mathrm{R}=\mathrm{Ph})$ and $2 \mathrm{f}(\mathrm{R}=\mathrm{Me})$ at $140{ }^{\circ} \mathrm{C}$ for $15 \mathrm{~min}$. It was earlier found that the reaction with 1 -azadiene $\mathbf{2 e}$ provided the spiro hydropyridin-2-one $\mathbf{3 e}$ in $70 \%$ yield [16]. The same reaction conducted with azadiene $\mathbf{2} \mathbf{f}$ provided only the 1,3-oxazin-4-one $\mathbf{4 f}$ albeit in low yield.

The influence of the nature of the $\alpha$-oxoketene on periselectivity was also evaluated experimentally. The six-membered cyclic $\alpha$-oxoketene $\mathbf{1 b}$ derived from the thermal Wolff rearrangement of 2-diazocycloheptan-1,3-dione was reacted with 1-azadiene $2 \mathrm{~g}$ at $160{ }^{\circ} \mathrm{C}$ to afford cleanly the 1,3-oxazin-4-one $4 \mathrm{~g}$, while the same reaction mixture at $200{ }^{\circ} \mathrm{C}$ for a prolonged time previously afforded the spiro hydropyridin-2-one $3 \mathrm{~g}$ in 53\% yield (Scheme 3a) [16]. The aza-Diels-Alder reaction of the acyclic $\alpha$-oxoketene $1 \mathrm{c}$ with the 1 -azadiene $2 \mathrm{~h}$ was also examined and found to lead to the 1,3-oxazin-4-one $4 \mathrm{~h}$ when conducted at $140{ }^{\circ} \mathrm{C}$ for $5 \mathrm{~min}$, while the same reaction performed at $200{ }^{\circ} \mathrm{C}$ for $15 \mathrm{~min}$ resulted in the exclusive formation of iso-3h (Scheme $3 \mathrm{~b}$ ). Significantly, the relative stereochemistry in iso-3h is opposite to the stereochemistry that has been described so far in this and other series of cycloadditions of $\alpha$-oxoketenes with $4 \pi$ reaction partners $[11,16,17]$. Ultimately, it was shown that $\alpha$-oxoketene $1 \mathrm{~d}$ derived from the Wolff rearrangement of methyl 2-diazoacetylacetate 
reacted with the 1-azadiene $2 \mathbf{i}$ at $160{ }^{\circ} \mathrm{C}$ to give the 1,3-oxazin-4-one $4 \mathbf{i}$ in $43 \%$ yield, and no reaction at higher temperature was attempted.

(a)<smiles>CC1(C)CC(=O)C(C(=O)C2CCCC2)C1</smiles>
$1 a$

$2 a$ $\overrightarrow{\text { toluene, } \mathrm{T}, \mathrm{t}}$

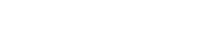

for $\mathrm{T}=140^{\circ} \mathrm{C}$ and $\mathrm{t}=15 \mathrm{~min}: \mathbf{3 a} / \mathbf{4 a}=2: 1,38 \%$ isolated $\mathbf{3 a}, 21 \%$ isolated $\mathbf{4 a}$ for $\mathrm{T}=150^{\circ} \mathrm{C}$ and $\mathrm{t}=30 \mathrm{~min}: \mathbf{3 a} / \mathbf{4 a}>25: 1,22 \%$ isolated $\mathbf{3 a}$ for $\mathrm{T}=160^{\circ} \mathrm{C}$ and $\mathrm{t}=15 \mathrm{~min}: \mathbf{3 a} / \mathbf{4 a}>25: 1,24 \%$ isolated $\mathbf{3 a}($ ref 16$)$

(b)

(c)

(d)

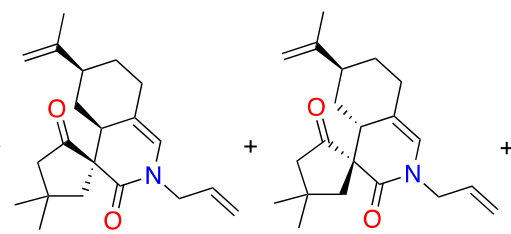

$3 \mathbf{b}(\mathrm{dr}=4: 1)$
$1 \mathrm{a}$<smiles>C=CCN=CC1=CCC(C(=C)C)CC1</smiles>

2b $\overrightarrow{\text { toluene, } \mathrm{T}, \mathrm{t}}$

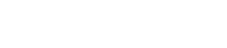

for $\mathrm{T}=140^{\circ} \mathrm{C}$ and $\mathrm{t}=15 \mathrm{~min}: \mathbf{3 b} / \mathbf{4 b}<1: 25,59 \%$ isolated $\mathbf{4 b}$ for $\mathrm{T}=200^{\circ} \mathrm{C}$ and $\mathrm{t}=15 \mathrm{~min}: \mathbf{3 b} / \mathbf{4 b}>25: 1,47 \%$ isolated $\mathbf{3 b}$ (ref 16 )

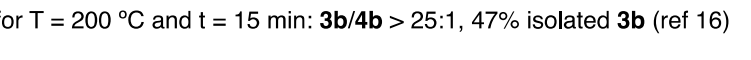

$1 \mathrm{a}+\overbrace{\mathrm{N}} \widehat{\mathrm{Ph}}_{\mathrm{Ph}} \underset{\text { toluene, } \mathrm{T}, \mathrm{t}}{\longrightarrow}$

2c

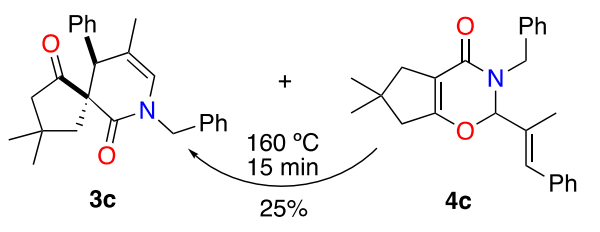

for $\mathrm{T}=140^{\circ} \mathrm{C}$ and $\mathrm{t}=15 \mathrm{~min}: 3 \mathrm{c} / 4 \mathrm{c}=2: 1$

for $\mathrm{T}=160^{\circ} \mathrm{C}$ and $\mathrm{t}=15 \mathrm{~min}: \mathbf{3 c} / \mathbf{4 c}>25: 1,74 \%$ isolated $3 \mathrm{c}$ (ref 16)

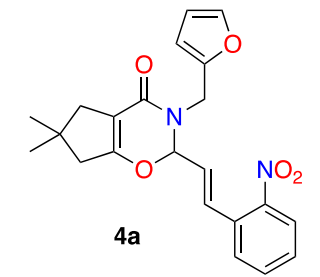

(1)

$1 \mathrm{a}+\mathrm{Ph} \overbrace{\mathrm{Cl}} \widehat{\mathrm{Ph}} \underset{\text { toluene, } \mathrm{T}, \mathrm{t}}{\stackrel{\mathrm{T}}{\longrightarrow}}$

2d

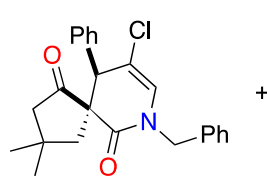

3d (not detected)<smiles>CC1(C)CC2=C(C1)C(=O)N(Cc1ccccc1)C(/C(Cl)=C/c1ccccc1)O2</smiles>

4d

for $\mathrm{T}=140^{\circ} \mathrm{C}$ and $\mathrm{t}=15 \mathrm{~min}: \mathbf{3 d} / \mathbf{4 d}<1: 25,61 \%$ isolated $\mathbf{4 d}$ for $\mathrm{T}=200^{\circ} \mathrm{C}$ and $\mathrm{t}=15 \mathrm{~min}: 3 \mathrm{~d} / \mathbf{4 d}<1: 25$, ca. $25 \%$ 4d (crude)

(e)

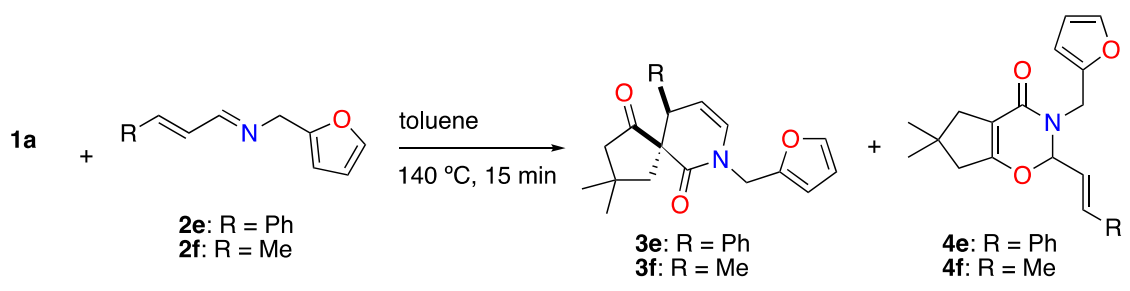

for $\mathrm{R}=\mathrm{Ph}: \mathbf{3 e} / \mathbf{4 e}>25: 1,70 \%$ isolated $3 \mathbf{e}($ ref 16$)$

for $R=$ Me: $\mathbf{3 f} / \mathbf{4 f}<1: 25,20 \%$ isolated $\mathbf{4 f}$

Scheme 2. Temperature dependence of the periselectivity in the formal aza-Diels-Alder cycloadditions between 1-azadienes $\mathbf{2 a - f}$ and $\alpha$-oxoketene $\mathbf{1 a}$. 
(a)

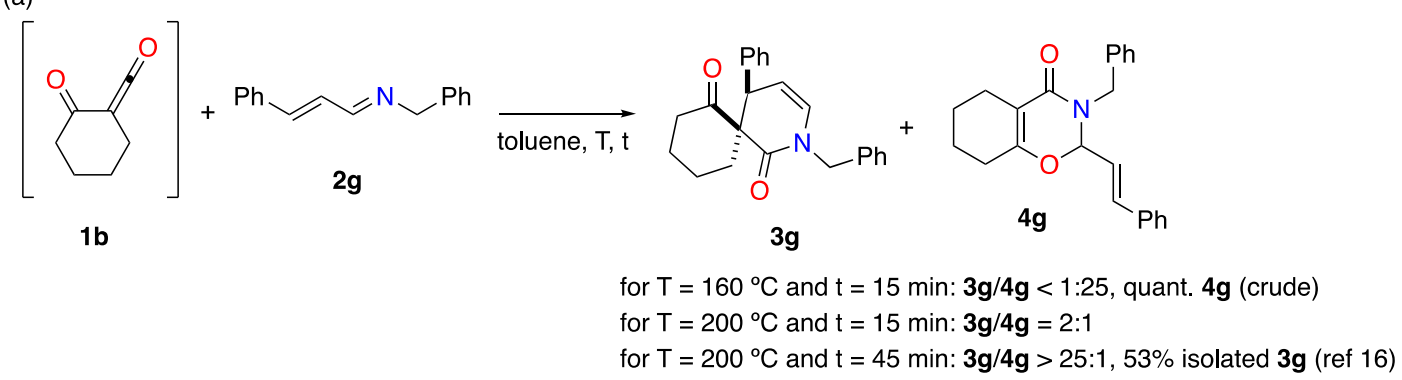

(b)<smiles>CCCN=C/C=C/c1ccccc1</smiles><smiles>CCCN1C=C[C@H](c2ccccc2)[C@@](C)(C(C)=O)C1=O</smiles>

for $\mathrm{T}=140^{\circ} \mathrm{C}$ and $\mathrm{t}=5 \mathrm{~min}$ : iso-3h/4h $<1: 25,78 \%$ isolated $\mathbf{4 h}$ for $\mathrm{T}=200^{\circ} \mathrm{C}$ and $\mathrm{t}=5 \mathrm{~min}$ : iso-3h/4h=3:1

for $\mathrm{T}=200^{\circ} \mathrm{C}$ and $\mathrm{t}=15 \mathrm{~min}$ : iso-3h/4h $>25: 1,38 \%$ isolated iso-3h

(c)

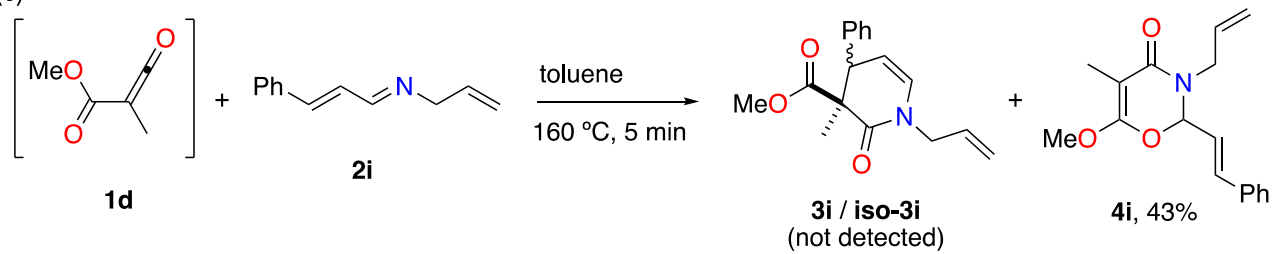

Scheme 3. Temperature dependence of the periselectivity in the formal aza-Diels-Alder cycloadditions between 1 -azadienes $\mathbf{2 g - i}$ and $\alpha$-oxoketenes $\mathbf{1} \mathbf{b}-\mathbf{d}$.

These new experimental data indicate that periselectivity in the aza-Diels-Alder cycloadditions between $\alpha$-oxoketenes and 1-azadienes is generally controlled by competitive kinetic and thermodynamic factors. However, there are some marked differences in reactivity within relatively homogeneous series of substrates, which called for rationalization to enable further developments and applications. To do so, the problem was tackled through computational modeling using density functional theory (DFT) methods. The $\alpha$-oxoketenes $\mathbf{1 b}, \mathbf{c}$ and $\mathbf{1 e}$ and the model $\mathbf{1}$-azadienes $\mathbf{2} \mathbf{j}-\mathbf{m}$ were selected for this part of the work. All calculations were performed using the B3LYP-D3/6-311++G(d,p) level of theory. Free Gibbs energies were generally computed at $298 \mathrm{~K}$ corresponding to the temperature of isolation of the products, and additionally at the reaction temperature for kinetically meaningful steps (see the Supplementary Materials for details of the calculations).

First, we examined the reactions between the $\alpha$-oxoketene $1 \mathbf{e}$ and the 1 -azadiene $2 \mathbf{j}$ to afford either the spiro hydropyridin-2-one $\mathbf{3} \mathbf{j}$ or the 1,3 -oxazin-4-one $\mathbf{j} \mathbf{j}$ (Figure $1 \mathbf{a}, \mathbf{b})$. As expected, formation of $\mathbf{3} \mathbf{j}$ was found largely thermodynamically favored when compared to the formation of $4 \mathrm{j}[\Delta(\Delta \mathrm{G})=-56.1 \mathrm{~kJ} / \mathrm{mol}]$ with barriers computed at $\Delta\left(\Delta \mathrm{G}^{\neq}\right)=12.1 \mathrm{~kJ} / \mathrm{mol}$ at $298 \mathrm{~K}$ and $18.9 \mathrm{~kJ} / \mathrm{mol}$ at $413 \mathrm{~K}$, which is fully consistent with the experimental results in Scheme 2a. However, the actual aza-Diels-Alder thermodynamic product of the reaction was computationally identified as iso- $\mathbf{3} \mathbf{j}$ (the diastereomer of $\mathbf{3} \mathbf{j}$ ) with a relative free Gibbs energy determined at $-75.8 \mathrm{~kJ} / \mathrm{mol}$, that is more stable than $3 \mathbf{j}$ by a tiny but meaningful $-2.4 \mathrm{~kJ} / \mathrm{mol}$; modeling its formation indicated a relative activation energy of $\Delta \mathrm{G}^{\neq}=73.9 \mathrm{~kJ} / \mathrm{mol}$ at $298 \mathrm{~K}$ and $100.5 \mathrm{~kJ} / \mathrm{mol}$ at $413 \mathrm{~K}$ plausible with its formation under the actual reaction conditions (Figure 1c). Because the diastereoselectivity in the model molecule iso-3j has never been reported experimentally in cycloadditions of $\alpha$-oxoketene $1 \mathbf{e}$ with any $4 \pi$ reaction partner [11,16,17], a competing process is certainly at hand. Actually, the formation of iso- $3 \mathbf{j}$ through TS6 was found kinetically outcompeted by the cyclodimerization of $\alpha$-oxoketene 1e (Figure 1c) that occurs with a significantly 
lower relative activation energy through TS7 to give dimer-1e, a molecule itself amenable to further thermodynamically driven transformations under the reaction conditions [11].

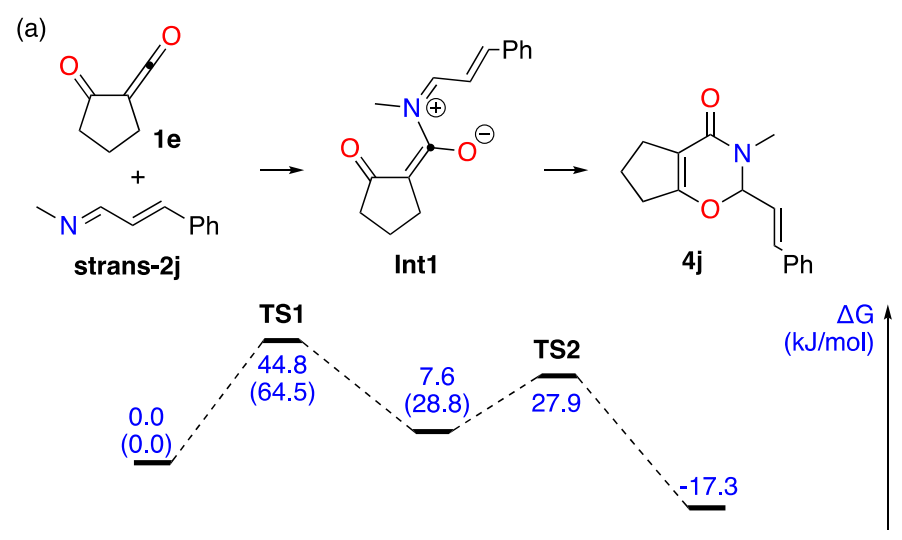

(b)

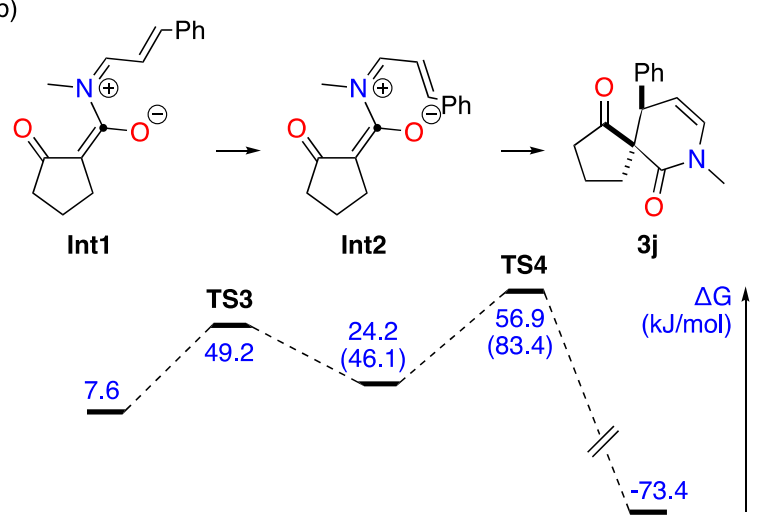

(c)

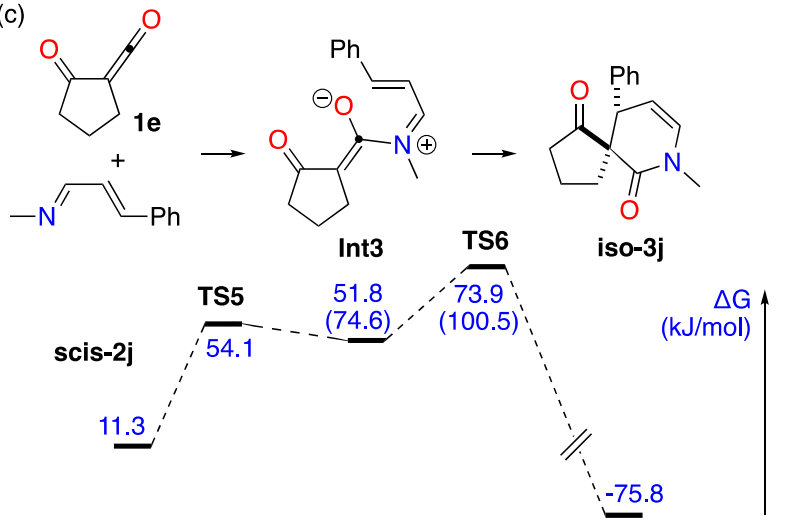

(d)

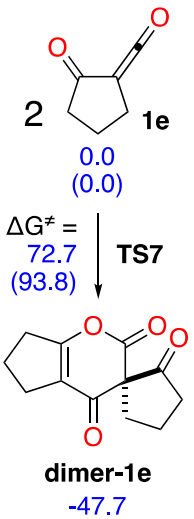

Figure 1. Free Gibbs energy profiles computed at $298 \mathrm{~K}$ (DFT, B3LYP-D3/6-311++G(d,p)) of the aza-Diels-Alder reactions between the $\alpha$-oxoketene $\mathbf{1 e}$ and the 1-azadiene $\mathbf{2} \mathbf{j}$, and cyclodimerization of $\alpha$-oxoketene 1e. Free Gibbs energies noted between parentheses were computed at $413 \mathrm{~K}$.

The aza-Diels-Alder reactions of $\alpha$-oxoketene $1 \mathbf{e}$ with the 3-substituted 1-azadienes $\mathbf{2 k}$ (Figure 2) and 21 (Figure 3) were next examined in silico for comparison with the experimental results in Scheme 2c,d. As above, formation of the 1,3-oxazin-4-ones $4 \mathbf{k}$ and $4 \mathbf{1}$ was found kinetically preferred to the formation of the corresponding spiro hydropyridin-2-ones of $3 \mathbf{k}$ and $3 \mathbf{1}$, with two competing reaction paths identified for the formation of $4 \mathbf{l}$ (Figure 3a). This is in agreement with the experimentally observed formation of both 1,3-oxazin-4-ones $4 \mathbf{c}$ and $4 \mathbf{d}$ from reactions at $140{ }^{\circ} \mathrm{C}$. However, at $160{ }^{\circ} \mathrm{C}$, the methyl-substituted spiro hydropyridin-2-one 3c (Scheme 2c) corresponding to the model molecule 3k (Figure 2b) was obtained experimentally, while somehow unexpectedly the chloro-substituted spiro hydropyridin-2-one $3 \mathbf{d}$ (Scheme $2 \mathrm{~d}$ ) corresponding to the model molecule 31 (Figure 3b) could not be 
obtained even at $200^{\circ} \mathrm{C}$. The rationalization of this experimental fact came from the comparison of the relative activation energies for the formation of $3 \mathbf{k}, 31$, and dimer-1e at $200{ }^{\circ} \mathrm{C}$ : TS11 leading to $3 \mathrm{k}$ competes favorably with the formation of dimer-1e through TS7, though not by much with $\Delta\left(\Delta \mathrm{G}^{\neq}\right)=$ $-3.5 \mathrm{~kJ} / \mathrm{mol}$ at $473 \mathrm{~K}$, while TS17 leading to 31 competes unfavorably with the formation of dimer-1e with $\Delta\left(\Delta \mathrm{G}^{\neq}\right)=3.4 \mathrm{~kJ} / \mathrm{mol}$ at $473 \mathrm{~K}$.

(a)<smiles>C[C@H]1CCC(=O)C1=O</smiles><smiles>CN=C/C(C)=C/c1ccccc1</smiles>
strans-2k

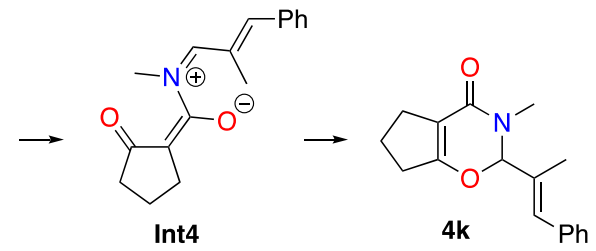

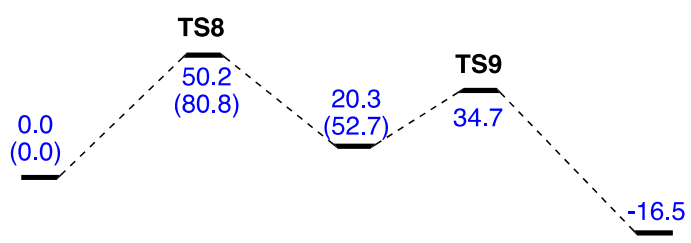

$(\mathrm{kJ} / \mathrm{mol})$

(b)<smiles>C/C(=C\c1ccccc1)N(C)C(O)=C1CCCC1=O</smiles>

Int4

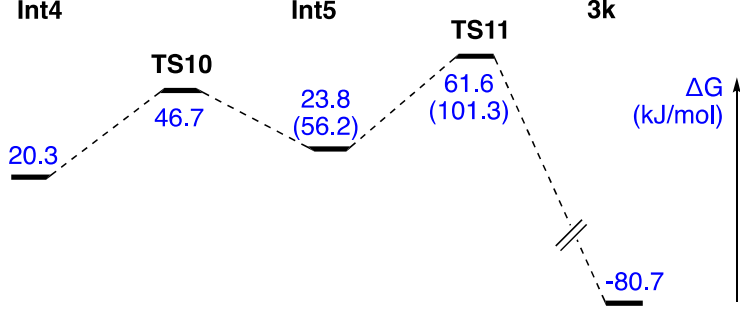

(c)
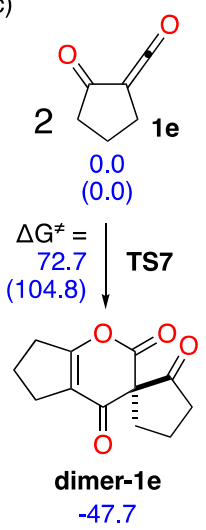

Figure 2. Free Gibbs energy profiles computed at 298 (DFT, B3LYP-D3/6-311++G(d,p)) of the aza-Diels-Alder reactions between the $\alpha$-oxoketene $\mathbf{1 e}$ and the 1 -azadiene $\mathbf{2 k}$, and cyclodimerization of $\alpha$-oxoketene 1e. Free Gibbs energies noted between parentheses were computed at $473 \mathrm{~K}$.

To conclude with the modeling of reactions of the cyclic five-membered $\alpha$-oxoketene 1e with 1-azadienes, the influence of a 4-phenyl or a 4-methyl substituent on the 1-azadiene was investigated to rationalize the results in Scheme 2e. Comparison of the energy profiles of the reactions $\alpha$-oxoketene 1e with the model 1-azadienes $\mathbf{2} \mathbf{j}$ (Figure 1) and $\mathbf{2 m}$ (Figure 4) essentially shows that the formation of the model spiro hydropyridin-2-one $3 \mathrm{~m}$ bearing a methyl substituent is significantly slower than the reaction leading to the model spiro hydropyridin-2-one $3 \mathbf{j}$ bearing a phenyl substituent with $\Delta\left(\Delta \mathrm{G}^{\neq}\right)=12.4 \mathrm{~kJ} / \mathrm{mol}$ at $298 \mathrm{~K}$ and $34.8 \mathrm{~kJ} / \mathrm{mol}$ at $413 \mathrm{~K}$ (compare TS4 with TS21). The relative increase in the activation energy induced by the 4-methyl substituent is significant and precludes the formation of the corresponding spiro hydropyridin-2-one $3 \mathrm{~m}$ at the benefit of the $\alpha$-oxoketene cyclodimer dimer-1e for kinetic reasons. Altogether, the selected DFT model allowed a faultless rational of the periselectivity in the reactions of $\alpha$-oxoketene 1e with 1-azadienes, which was found to be governed by a combination of kinetic and thermodynamic factors. 
(a)
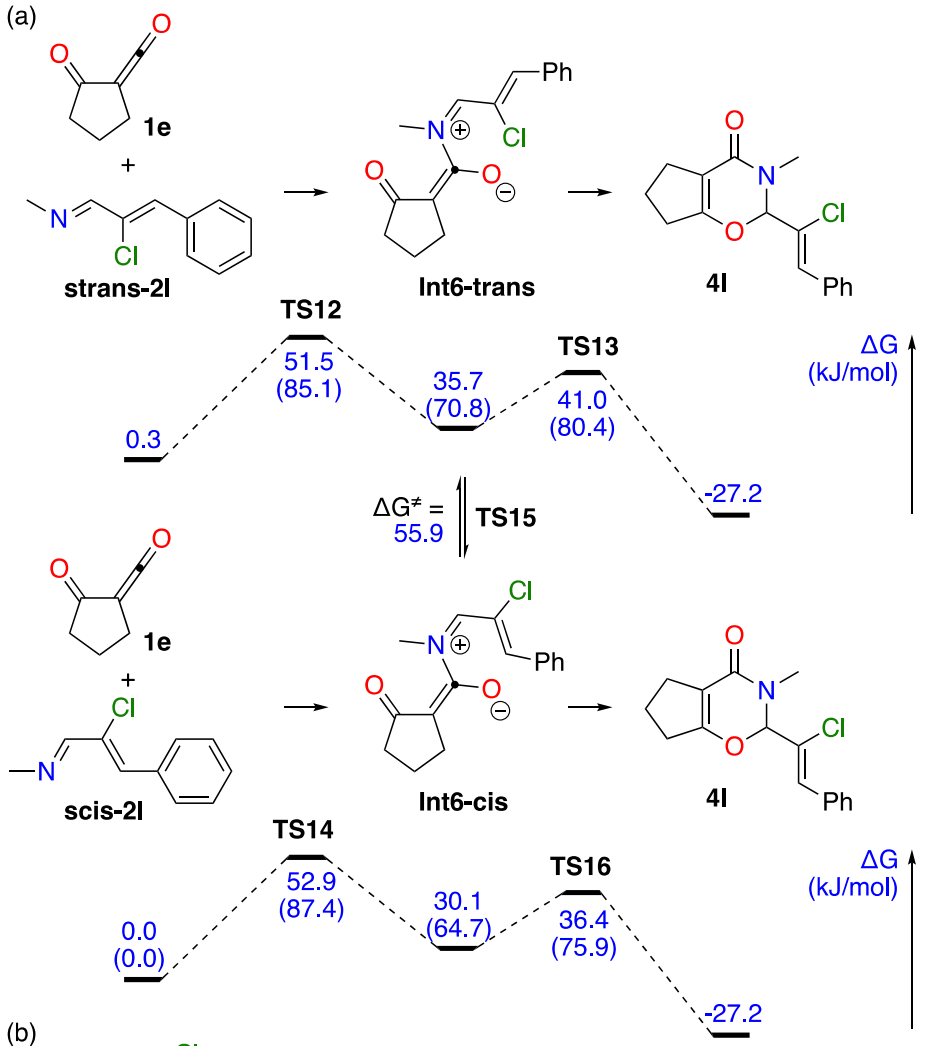

(b)

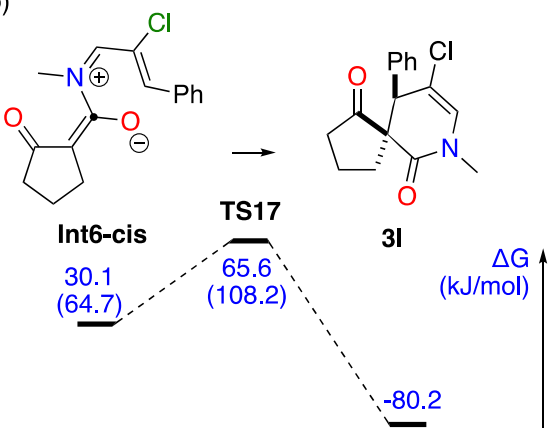

Figure 3. Free Gibbs energy profiles computed at $298 \mathrm{~K}$ (DFT, B3LYP-D3/6-311++G(d,p)) of the aza-Diels-Alder reactions between the $\alpha$-oxoketene $1 \mathbf{e}$ and the 1-azadiene 21 . Free Gibbs energies noted between parentheses were computed at $473 \mathrm{~K}$. For 1 -azadiene 21 , the s-cis/s-trans denomination refers to the conformation of the $4 \pi$ system of the 1 -azadiene, not to the regular CIP nomenclature.

Calculations with the cyclic six-membered $\alpha$-oxoketene $\mathbf{1 b}$ (Figure 5) paralleled the previous findings and were also found in full agreement with the experimental results, with the actual thermodynamic diastereomer of the spiro hydropyridin-2-one product being computationally identified as iso-3n, that is not the model molecule corresponding to the experimentally observed diastereomer $\mathbf{3 g}$ from the reaction at $200^{\circ} \mathrm{C}$ (Scheme 3a). At $200^{\circ} \mathrm{C}$, there are two orders of magnitude between the kinetic constants estimated for the formation of $3 \mathrm{n}$ via TS25 and iso-3n via TS27 (circa $\mathrm{k}=60 \mathrm{~s}^{-1}$ and $0.56 \mathrm{~s}^{-1}$, respectively), but the formation of iso-3n remains plausible after $45 \mathrm{~min}$ at $20{ }^{\circ} \mathrm{C}$. It should, however, be considered that the ratio Int10/Int11 is higher than 104:1 according to the model, which precludes the formation of iso-3n at a significant rate under the examined experimental conditions (relative rates in the magnitude of $10^{6}: 1$ ). Additionally, the cyclodimerization of $\alpha$-oxoketene $\mathbf{1 b}$ to give dimer- $\mathbf{1 b}$ through TS28 is also in competition with the formation of iso-3n at $200^{\circ} \mathrm{C}$. On this occasion, again, the selected DFT model allowed for a complete rationalization of the periselectivity in the reactions of $\alpha$-oxoketene $\mathbf{1 b}$ with 1 -azadienes, which was found to be governed by a combination of kinetic and thermodynamic factors, as for $\alpha$-oxoketene 1 e. 
(a)

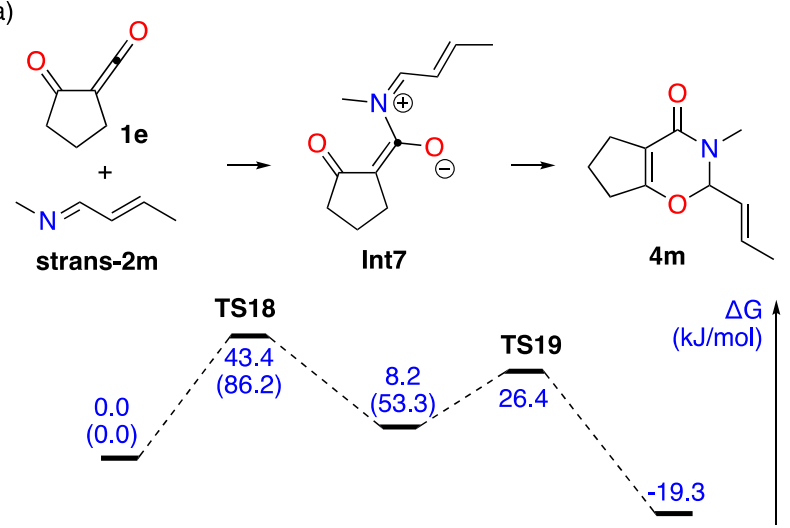

(b)

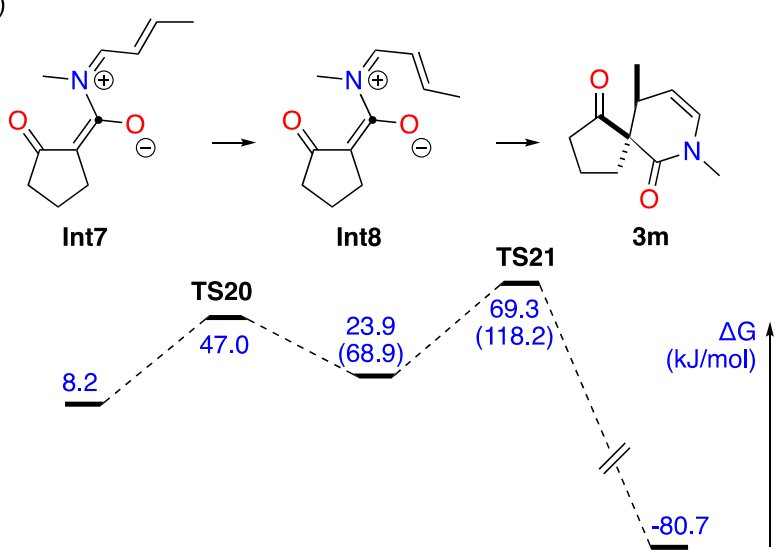

Figure 4. Free Gibbs energy profiles computed at $298 \mathrm{~K}$ (DFT, B3LYP-D3/6-311++G(d,p)) of the aza-Diels-Alder reactions between the $\alpha$-oxoketene $1 \mathbf{e}$ and the 1 -azadiene $\mathbf{2} \mathbf{m}$. Free Gibbs energies noted between parentheses were computed at $413 \mathrm{~K}$.

The calculations in the acyclic series were complicated by the existence of the additional s-trans conformer of the $\alpha$-oxoketene 1c (Figure 6a) but again were in full agreement with the experiments. As expected, 40 was identified as the kinetic aza-Diels-Alder product in the model reaction between $\alpha$-oxoketene $1 \mathrm{c}$ and 1-azadiene $2 \mathbf{j}$ with $\Delta \mathrm{G}^{\neq}=70.7 \mathrm{~kJ} / \mathrm{mol}$ at $298 \mathrm{~K}$ and $102.5 \mathrm{~kJ} / \mathrm{mol}$ at $473 \mathrm{~K}$. As above, the true thermodynamic cycloadduct was identified as iso-3o with notably a more pronounced difference in stabilization energy between the two diastereomers 3o/iso-3o than in the previous cases for $\mathbf{3} \mathbf{j} / \mathbf{i s o - 3 \mathbf { j }}$ (Figure 1) and $\mathbf{3 n}$ /iso-3n (Figure 5). In addition, the difference between the activation energies leading to one or the other diastereomer is reduced in this series with $\Delta\left(\Delta \mathrm{G}^{\neq}\right)=10.3 \mathrm{~kJ} / \mathrm{mol}$ at $298 \mathrm{~K}$ and $10.9 \mathrm{~kJ} / \mathrm{mol}$ at $473 \mathrm{~K}$ for TS33/TS35. This is to be compared with $\Delta\left(\Delta \mathrm{G}^{\neq}\right)=17.0 \mathrm{~kJ} / \mathrm{mol}$ at $298 \mathrm{~K}$ and $17.1 \mathrm{~kJ} / \mathrm{mol}$ at $473 \mathrm{~K}$ for TS4/TS6, and $\Delta\left(\Delta \mathrm{G}^{\neq}\right)=18.8 \mathrm{~kJ} / \mathrm{mol}$ at $298 \mathrm{~K}$ and $18.4 \mathrm{~kJ} / \mathrm{mol}$ at $473 \mathrm{~K}$ for TS25/TS27. The difference between the estimated kinetic constants corresponding to TS33 and TS35 is now reduced to a single order of magnitude (circa k $=0.49 \mathrm{~s}^{-1}$ and $0.031 \mathrm{~s}^{-1}$ for TS33 and TS35 at $200{ }^{\circ} \mathrm{C}$, respectively), allowing for both processes to compete at $200{ }^{\circ} \mathrm{C}$. In this case, the cyclodimerization of the $\alpha$-oxoketene 1c (via TS36) was found not to compete kinetically with the aza-Diels-Alder processes examined. Altogether, the calculations indicate that in the case of the acyclic $\alpha$-oxoketene 1c, and only in this case, the actual thermodynamic product of the reaction iso-3o can be obtained, which was demonstrated experimentally with the isolation of iso-3h (Scheme $3 \mathrm{~b}$ ). 

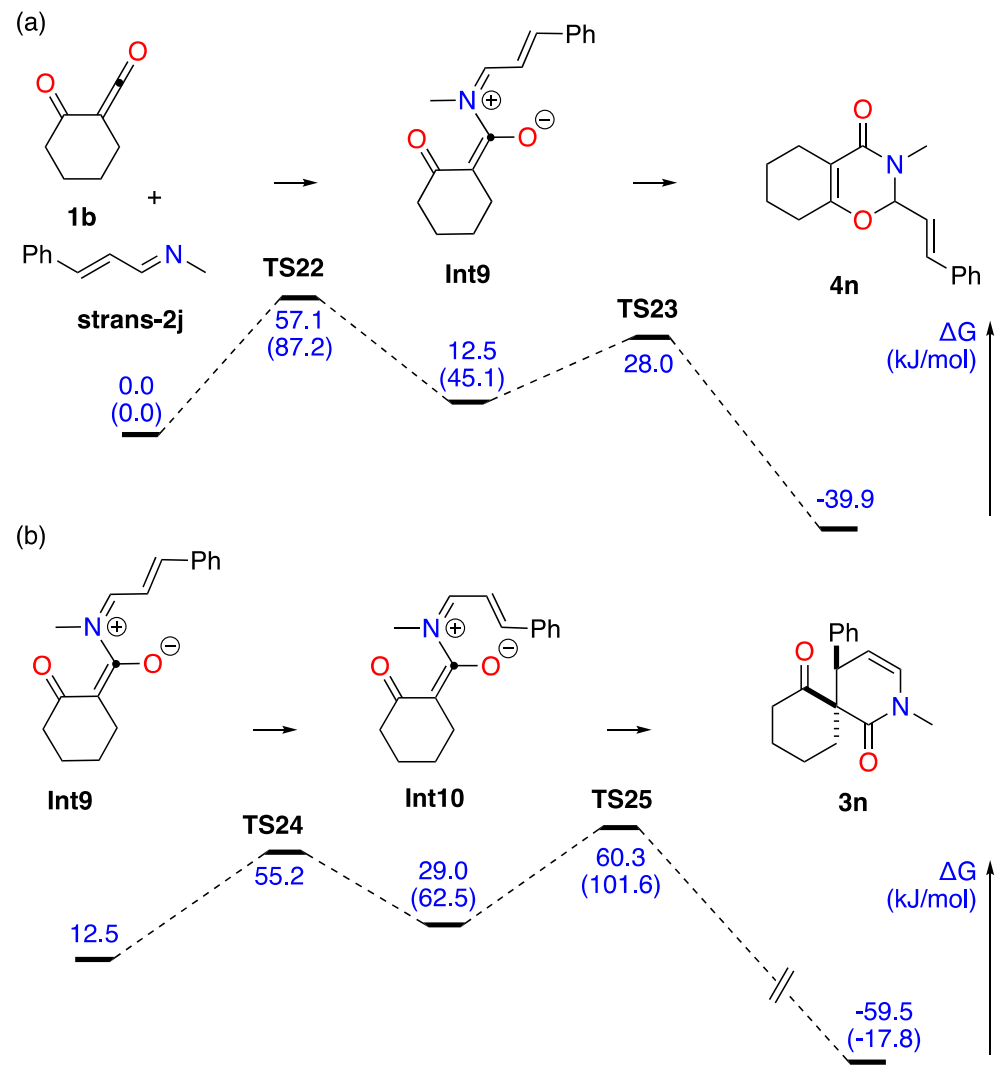

(c)
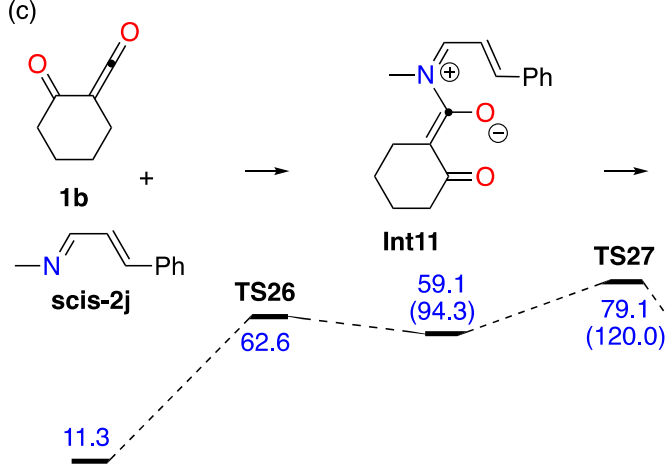

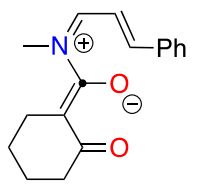

Int11
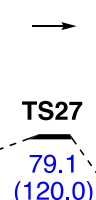<smiles>CN1C=C[C@@H](c2ccccc2)[C@]2(CCCCC2=O)C1=O</smiles>

iso-3n

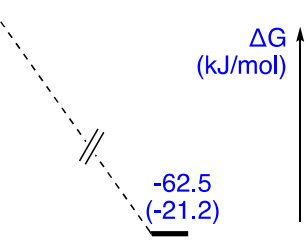

(d)
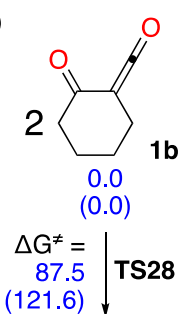

(121.6)<smiles>O=C1CCCC[C@]12C(=O)OC1=C(CCCC1)C2=O</smiles>

dimer-1b

$-61.2$

Figure 5. Free Gibbs energy profiles computed at $298 \mathrm{~K}$ (DFT, B3LYP-D3/6-311++G(d,p)) of the aza-Diels-Alder reactions between the $\alpha$-oxoketene $\mathbf{1} \mathbf{b}$ and the 1 -azadiene $\mathbf{2 j}$. Free Gibbs energies noted between parentheses were computed at $473 \mathrm{~K}$.

All the aza-Diels-Alder processes described herein are stepwise processes, occurring first with the formation of the $\mathrm{N}-\mathrm{C}$ bond to produce a zwitterionic intermediate and then cyclization to the product with formation of the $\mathrm{C}-\mathrm{C}$ or $\mathrm{O}-\mathrm{C}$ bond. These processes should thus preferably be referred to as formal aza-Diels-Alder cycloadditions. The physical reason at the origin of this behavior is that the LUMO of all the $\alpha$-oxoketenes are essentially located over the ketene carbonyl groups, not over the two or four $\mathrm{sp}^{2}$ hybridized atoms involved in the cycloaddition, and directed in the mean plane of the $\alpha$-oxoketenes, not perpendicular to it as in standard Diels-Alder cycloadditions (Figure 7). Actually, the LUMO +1 of the $\alpha$-oxoketenes are mostly distributed over the $\alpha$-oxo carbonyl groups and the ketene $\mathrm{C}=\mathrm{C}$ bonds and oriented perpendicular to the molecular plane [11], but with a significant LUMO/LUMO+1 gap of $0.01453 \mathrm{Ha}$ or $38.1 \mathrm{~kJ} / \mathrm{mol}$ on average, and no transition states accounting for the symmetry-allowed concerted transformations were located computationally during this work. 
(a)

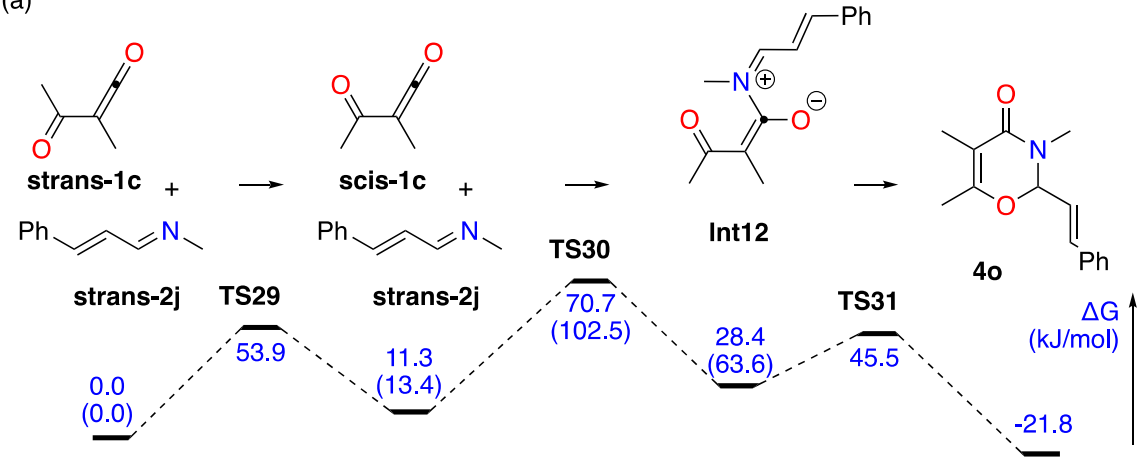

(b)

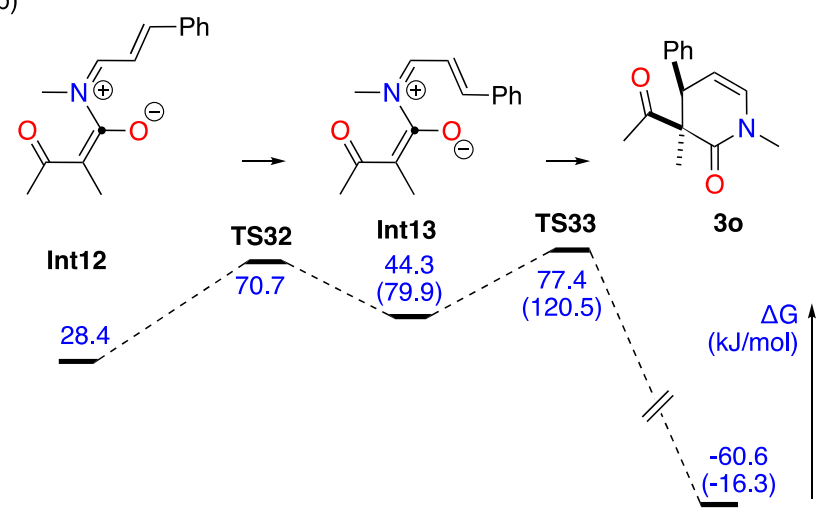

(c)
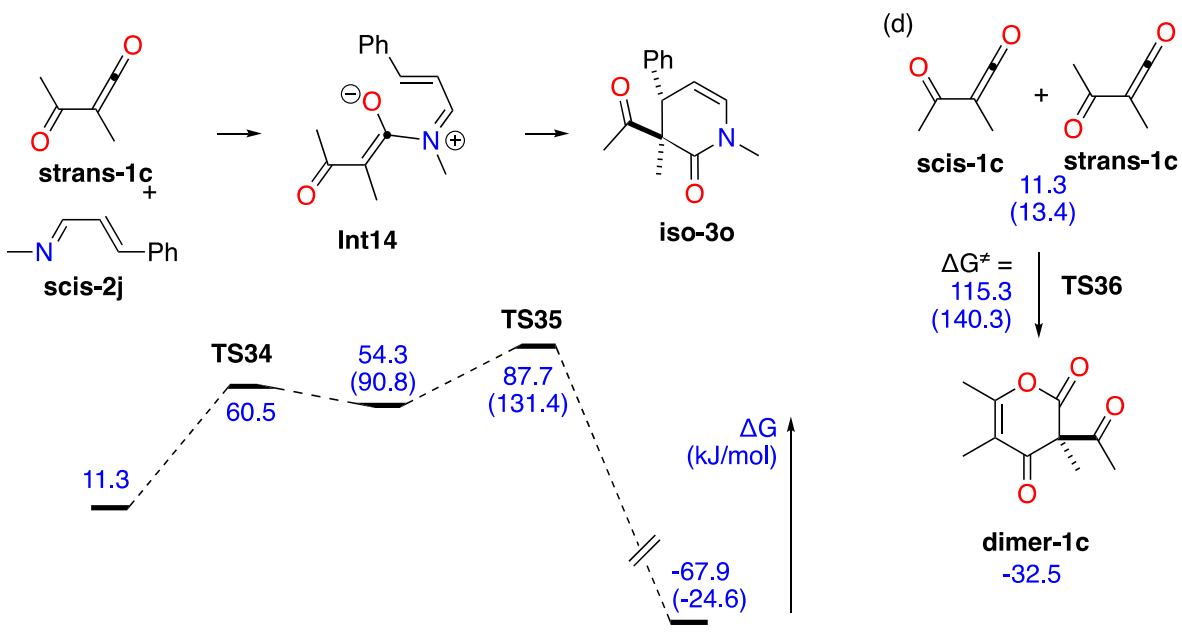

dimer-1c $-32.5$

Figure 6. Free Gibbs energy profiles computed at $298 \mathrm{~K}$ (DFT, B3LYP-D3/6-311++G(d,p)) of the aza-Diels-Alder reactions between the $\alpha$-oxoketene $1 \mathrm{c}$ and the 1 -azadiene $\mathbf{2 j}$. Free Gibbs energies noted between parentheses were computed at $473 \mathrm{~K}$.

In the course of the computational investigations summarized herein, some alternative kinetically, and for the most also thermodynamically, disfavored reaction paths leading to other cycloadducts were identified; this includes $\beta$-lactams resulting from formal [2+2] cycloadditions between the $C=C$ bond of the ketene and the $\mathrm{C}=\mathrm{N}$ bond of the 1-azadiene, and 1,3-oxazin-2-ylidenes resulting from a formal [4+2] cycloaddition between the $\mathrm{C}=\mathrm{O}$ bond of the ketene and the $4 \pi$ system of the 1 -azadiene. 

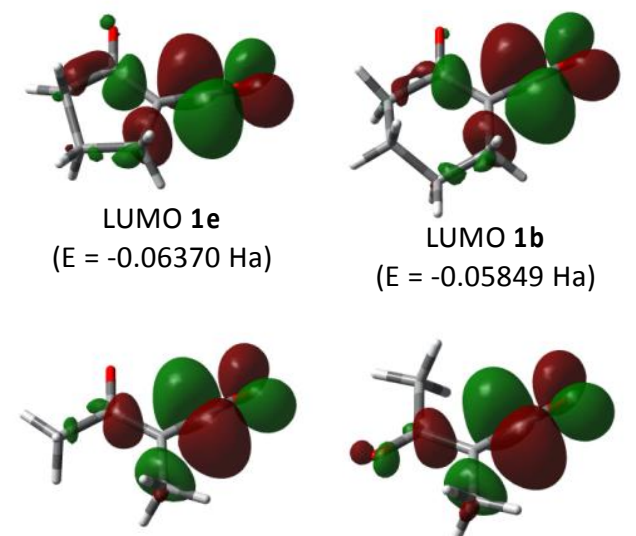

LUMO scis-1c

( $E=-0.05929 \mathrm{Ha}$ )

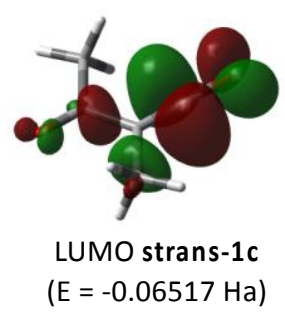

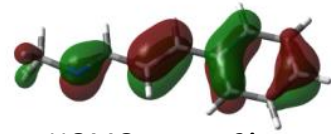

HOMO strans-2j

( $E=-0.23235 \mathrm{Ha}$ )

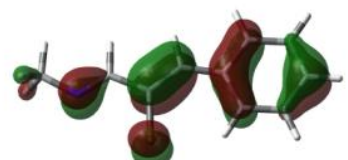

HOMO strans-2I

$(E=-0.23679 \mathrm{Ha})$

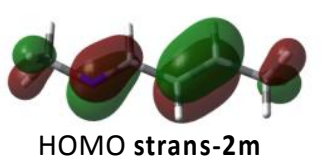

$(\mathrm{E}=-0.25125 \mathrm{Ha})$

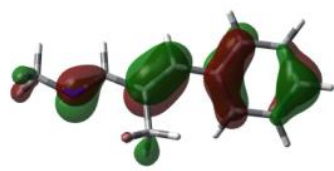

HOMO strans-2k

( $E=-0.23109 \mathrm{Ha}$ )

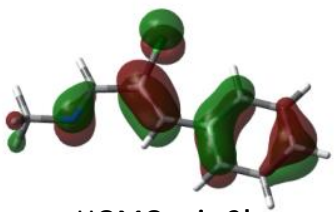

HOMO scis-2I

( $E=-0.23324 \mathrm{Ha}$ )

Figure 7. Contour plots of the lowest unoccupied molecular orbitals (LUMOs) in the $\alpha$-oxoketenes 1e, 1b, scis-1c, and strans-1c, and those of the highest occupied molecular orbitals (HOMOs) of the model 2-azadienes strans-2j, strans-2k, strans-2l, scis-2l, and strans-2m.

\section{Experimental Section}

All reagents were purchased from commercial sources and used without further purification unless otherwise noted. All compounds were weighed and handled in air at room temperature. Microwave-assisted heating was performed using a professional Anton-Paar (Austria) Monowave 300 system in specific sealed tubular reaction vessels. The reactions were monitored by thin layer chromatography (TLC, $60 \mathrm{~F}_{254}$ ) visualized by UV lamp ( $254 \mathrm{~nm}$ or $365 \mathrm{~nm}$ ). Flash chromatography was performed on silica gel (particle size 40-63 $\mu \mathrm{m}$ ). Petroleum ether refers to the fraction with $\mathrm{bp}=40-60{ }^{\circ} \mathrm{C}$. NMR spectra were recorded at $300 \mathrm{MHz}\left({ }^{1} \mathrm{H}\right)$ and $75 \mathrm{MHz}\left({ }^{13} \mathrm{C}\right)$ at $298 \mathrm{~K}$ in $\mathrm{CDCl}_{3}$ using as internal standards the residual non-deuterated signal for ${ }^{1} \mathrm{H}-\mathrm{NMR}(\delta=7.26 \mathrm{ppm})$ and the deuterated solvent signal for ${ }^{13} \mathrm{C}$-NMR spectroscopy $(\delta=77.16 \mathrm{ppm})$. DEPT-135 experiments were used to determine the multiplicity of the ${ }^{13} \mathrm{C}$ resonances. Chemical shifts $(\delta)$ are given in ppm, coupling constants $(J)$ are given in $\mathrm{Hz}$, and the classical abbreviations are used to describe the multiplicity of the ${ }^{1} \mathrm{H}$ resonances. Copies of all NMR spectra are provided as Supplementary Materials for this article. High-resolution mass spectra were recorded in triplicate at the Spectropole (https://fr-chimie.univ-amu.fr/spectropole/). 2-Diazo-1,3-dicarbonyls were prepared as previously reported in similar yields and purity [18].

General procedure for the aza-Diels-Alder reactions: a solution of a primary amine (1 equiv) and an $\alpha, \beta$-unsaturated aldehyde ( 1 equiv) in $2-3 \mathrm{~mL}$ of anhydrous toluene (ca. $0.4 \mathrm{M}$ ) under an argon atmosphere in a microwave dedicated sealed tube containing a Teflon coated magnetic stirring bar was irradiated at $140{ }^{\circ} \mathrm{C}$ for $15 \mathrm{~min}$ (ramp up time $=2 \mathrm{~min}$ ), cooled down to $55^{\circ} \mathrm{C}$ by an air flow over 5-6 $\mathrm{min}$, and concentrated directly in the reaction vessel to afford the corresponding imine quantitatively as verified by ${ }^{1} \mathrm{H}-\mathrm{NMR}$ analysis. To this material placed under an argon atmosphere was added the diazo compound (1 equiv) and anhydrous toluene $(2-3 \mathrm{~mL}, \mathrm{ca} .0 .4 \mathrm{M})$, the reaction vessel was sealed, and this mixture was irradiated at the set temperature for the time indicated (after a temperature ramp-up time of ca. $2 \mathrm{~min}$ ). The resulting reaction mixture was cooled down to $55^{\circ} \mathrm{C}$ by an air flow over 5-6 min, concentrated, analyzed by NMR to determine the products ratio, and directly purified by flash chromatography when isolation was attempted.

4a: Following the general procedure, the reaction between ortho-nitrocinnamaldehyde (172 $\mathrm{mg}$, $0.97 \mathrm{mmol})$, furfurylamine $(86 \mu \mathrm{L}, 0.97 \mathrm{mmol})$, and 5,5-dimethyl-2-diazo-cyclohexan-1,3-dione (161 mg, $0.97 \mathrm{mmol})$ at $140{ }^{\circ} \mathrm{C}$ for $15 \mathrm{~min}$ afforded the spiro hydropyridin-2-one $3 \mathbf{a}(147 \mathrm{mg}, 38 \%)$ as a yellow oil and the 1,3-oxazin-4-one $4 \mathbf{a}(80 \mathrm{mg}, 21 \%)$ as a yellow oil. $\mathrm{Rf}(\mathrm{AcOEt} /$ petroleum ether 4:6) $=0.45$. HRMS (ESI+) $m / z$ : $[\mathrm{M}+\mathrm{H}]^{+}$calcd for $\mathrm{C}_{22} \mathrm{H}_{23} \mathrm{~N}_{2} \mathrm{O}_{5}{ }^{+} 395.1601$, found $395.1604 .{ }^{13} \mathrm{C}_{\{}\{\mathrm{H}\}-\mathrm{NMR}(75 \mathrm{MHz}$, 
$\left.\delta \mathrm{ppm} / \mathrm{CDCl}_{3}\right): 165.8(\mathrm{C}), 161.8(\mathrm{C}), 150.4(\mathrm{C}), 147.8(\mathrm{C}), 142.3(\mathrm{CH}), 133.4(\mathrm{CH}), 131.3(\mathrm{C}), 131.0(\mathrm{CH})$, $129.1(\mathrm{CH}), 128.9(\mathrm{CH}), 127.2(\mathrm{CH}), 124.7(\mathrm{CH}), 110.5(\mathrm{CH}), 108.8(\mathrm{CH}), 108.3(\mathrm{C}), 88.7(\mathrm{CH}), 46.2\left(\mathrm{CH}_{2}\right)$, $41.0\left(\mathrm{CH}_{2}\right), 38.6\left(\mathrm{CH}_{2}\right), 36.3(\mathrm{C}), 30.0\left(\mathrm{CH}_{3}\right), 29.9\left(\mathrm{CH}_{3}\right) .{ }^{1} \mathrm{H}-\mathrm{NMR}\left(300 \mathrm{MHz}, \delta \mathrm{ppm} / \mathrm{CDCl}_{3}\right): 7.99$ $(\mathrm{dd}, J=1.6,7.8 \mathrm{~Hz}, 1 \mathrm{H}), 7.59(\mathrm{ddd}, J=1.6,7.4,7.4 \mathrm{~Hz}, 1 \mathrm{H}), 7.50-7.43(\mathrm{~m}, 2 \mathrm{H}), 7.33(\mathrm{dd}, J=0.9,1.5 \mathrm{~Hz}, 1 \mathrm{H})$, $7.15(\mathrm{~d}, J=15.7 \mathrm{~Hz}, 1 \mathrm{H}), 6.32-6.23(\mathrm{~m}, 3 \mathrm{H}), 5.85(\mathrm{dd}, J=0.9,6.7 \mathrm{~Hz}, 1 \mathrm{H}), 4.90(\mathrm{~d}, J=15.8 \mathrm{~Hz}, 1 \mathrm{H})$, $4.40(\mathrm{~d}, J=15.8 \mathrm{~Hz}, 1 \mathrm{H}), 2.46-2.25(\mathrm{~m}, 4 \mathrm{H}), 1.15(\mathrm{~s}, 3 \mathrm{H}), 1.13(\mathrm{~s}, 3 \mathrm{H})$.

$4 \mathrm{~b}$ : Following the general procedure, the reaction between (-)-perillaldehyde $(155 \mu \mathrm{L}, 1.0 \mathrm{mmol})$, allylamine $(75 \mu \mathrm{L}, 1.0 \mathrm{mmol})$, and 5,5-dimethyl-2-diazo-cyclohexan-1,3-dione (166 mg, $1.0 \mathrm{mmol})$ at $140{ }^{\circ} \mathrm{C}$ for $15 \mathrm{~min}$ afforded the 1,3-oxazin-4-one $4 \mathbf{b}(193 \mathrm{mg}, 59 \%, \mathrm{dr}=1: 1)$ as a yellow oil. $\mathrm{Rf}\left(\mathrm{Et}_{2} \mathrm{O} /\right.$ petroleum ether 2:8) $=0.18$. HRMS (ESI+) $\mathrm{m} / \mathrm{z}:[\mathrm{M}+\mathrm{H}]^{+}$calcd for $\mathrm{C}_{21} \mathrm{H}_{30} \mathrm{NO}_{2}{ }^{+} 328.2271$, found 328.2271. ${ }^{13} \mathrm{C}\left\{{ }^{1} \mathrm{H}\right\}-\mathrm{NMR}\left(75 \mathrm{MHz}, \delta \mathrm{ppm} / \mathrm{CDCl}_{3}\right)$ : $165.3(\mathrm{C}), 164.9(\mathrm{C}), 163.0(\mathrm{C}), 162.7(\mathrm{C})$, $148.8(\mathrm{C}), 148.6(\mathrm{C}), 133.3(\mathrm{CH}), 133.3(\mathrm{CH}), 132.0(\mathrm{C}), 131.8(\mathrm{C}), 128.9(\mathrm{CH}), 128.2(\mathrm{CH}), 117.0\left(\mathrm{CH}_{2}\right)$, $116.9\left(\mathrm{CH}_{2}\right), 109.0\left(\mathrm{CH}_{2}\right), 109.0\left(\mathrm{CH}_{2}\right), 107.9(\mathrm{C}), 107.7(\mathrm{C}), 91.7(\mathrm{CH}), 91.3(\mathrm{CH}), 46.0\left(\mathrm{CH}_{2}\right), 46.0\left(\mathrm{CH}_{2}\right)$, $44.8\left(\mathrm{CH}_{2}\right), 44.6\left(\mathrm{CH}_{2}\right), 41.0\left(\mathrm{CH}_{2}\right), 40.9\left(\mathrm{CH}_{2}\right), 40.6(\mathrm{CH}), 40.2(\mathrm{CH}), 36.1(\mathrm{C}), 36.0(\mathrm{C}), 30.2\left(\mathrm{CH}_{2}\right)$, $30.0\left(\mathrm{CH}_{2}\right), 29.9\left(\mathrm{CH}_{3}\right), 29.9\left(\mathrm{CH}_{3}\right), 29.8\left(\mathrm{CH}_{3}\right), 29.7\left(\mathrm{CH}_{3}\right), 27.0\left(\mathrm{CH}_{2}\right), 26.7\left(\mathrm{CH}_{2}\right), 24.6\left(\mathrm{CH}_{2}\right), 23.6$ $\left(\mathrm{CH}_{2}\right), 20.7\left(\mathrm{CH}_{3}\right), 20.6\left(\mathrm{CH}_{3}\right) .{ }^{1} \mathrm{H}-\mathrm{NMR}\left(300 \mathrm{MHz}, \delta \mathrm{ppm} / \mathrm{CDCl}_{3}\right): 5.79-5.66(\mathrm{~m}, 4 \mathrm{H}), 5.46(\mathrm{br}, 2 \mathrm{H})$, $5.15-5.07(\mathrm{~m}, 4 \mathrm{H}), 4.10-4.65(\mathrm{~m}, 4 \mathrm{H}), 4.59-4.45(\mathrm{~m}, 2 \mathrm{H}), 3.31-3.20(\mathrm{~m}, 2 \mathrm{H}), 2.32-2.25(\mathrm{~m}, 8 \mathrm{H}), 2.16-1.90$ $(\mathrm{m}, 8 \mathrm{H}), 1.86-1.80(\mathrm{~m}, 2 \mathrm{H}), 1.69(\mathrm{~s}, 6 \mathrm{H}), 1.50-1.36(\mathrm{~m}, 2 \mathrm{H}), 1.21-1.14(\mathrm{~m}, 2 \mathrm{H}), 1.10(\mathrm{~s}, 6 \mathrm{H}), 1.08(\mathrm{~s}, 6 \mathrm{H})$.

4c: Following the general procedure, the reaction between $\alpha$-methyl-cinnamaldehyde $(140 \mu \mathrm{L}$, $1.0 \mathrm{mmol})$, benzylamine $(109 \mu \mathrm{L}, 1.0 \mathrm{mmol})$, and 5,5-dimethyl-2-diazo-cyclohexan-1,3-dione (167 mg, $1.0 \mathrm{mmol}$ ) at $140^{\circ} \mathrm{C}$ for $15 \mathrm{~min}$ afforded a $2: 1$ mixture of the 1,3-oxazin-4-one $3 \mathrm{c}$ and the 1,3-oxazin-4-one $4 \mathrm{c}(311 \mathrm{mg}, 82 \%$ total) that we failed at separating by flash chromatography. Some amount of 1,3-oxazin-4-one $4 \mathrm{c}$ could be isolated by treatment of the $3 \mathbf{c} / 4 \mathrm{c} 2: 1$ mixture by 0.75 equiv $\mathrm{NaBH}_{4}$ in ethanol followed by standard work-up and flash chromatography eluted with $\mathrm{Et}_{2} \mathrm{O} /$ petroleum ether 2:8

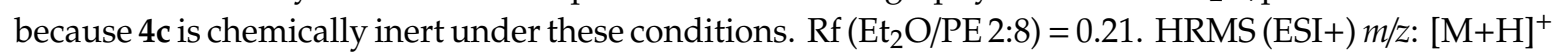
calcd for $\mathrm{C}_{25} \mathrm{H}_{28} \mathrm{NO}_{2}{ }^{+} 374.2115$, found $374.2111 .{ }^{13} \mathrm{C}\left\{{ }^{1} \mathrm{H}\right\}-\mathrm{NMR}\left(75 \mathrm{MHz}, \delta \mathrm{ppm} / \mathrm{CDCl}_{3}\right): 165.5$ (C), $163.2(\mathrm{C}), 137.4(\mathrm{C}), 135.8(\mathrm{C}), 131.4(\mathrm{CH}), 131.3(\mathrm{C}), 129.0(\mathrm{CH}), 129.0(\mathrm{CH}), 128.5(\mathrm{CH}), 128.5(\mathrm{CH})$, $128.3(\mathrm{CH}), 128.3(\mathrm{CH}), 127.8(\mathrm{CH}), 127.8(\mathrm{CH}), 127.3(\mathrm{CH}), 127.2(\mathrm{CH}), 107.7(\mathrm{C}), 93.5(\mathrm{CH}), 46.2\left(\mathrm{CH}_{2}\right)$, $45.7\left(\mathrm{CH}_{2}\right), 41.1\left(\mathrm{CH}_{2}\right), 36.2(\mathrm{C}), 30.0\left(\mathrm{CH}_{3}\right), 29.8\left(\mathrm{CH}_{3}\right), 13.9\left(\mathrm{CH}_{3}\right) .{ }^{1} \mathrm{H}-\mathrm{NMR}\left(300 \mathrm{MHz}, \delta \mathrm{ppm} / \mathrm{CDCl}_{3}\right)$ : 7.38-7.19 (m, 10H), $6.37(\mathrm{~s}, 1 \mathrm{H}), 5.65(\mathrm{~s}, 1 \mathrm{H}), 5.32(\mathrm{~d}, J=15.4 \mathrm{~Hz}, 1 \mathrm{H}), 3.96(\mathrm{~d}, J=15.4 \mathrm{~Hz}, 1 \mathrm{H}), 2.46-2.33$ $(\mathrm{m}, 4 \mathrm{H}), 1.90(\mathrm{~d}, J=1.2 \mathrm{~Hz}, 3 \mathrm{H}), 1.20(\mathrm{~s}, 3 \mathrm{H}), 1.16(\mathrm{~s}, 3 \mathrm{H})$.

$4 \mathrm{~d}$ : Following the general procedure, the reaction between $\alpha$-chloro-cinnamaldehyde (144 $\mathrm{mg}$, $0.86 \mathrm{mmol})$, benzylamine $(94 \mu \mathrm{L}, 0.86 \mathrm{mmol})$, and 5,5-dimethyl-2-diazo-cyclohexan-1,3-dione (144 mg, $0.86 \mathrm{mmol})$ at $140{ }^{\circ} \mathrm{C}$ for $15 \mathrm{~min}$ afforded the 1,3-oxazin-4-one $4 \mathrm{~d}(210 \mathrm{mg}, 61 \%)$ as a colorless oil. $\operatorname{Rf}\left(\mathrm{Et}_{2} \mathrm{O} /\right.$ petroleum ether 4:6) $=0.35$. MS $\left.(\mathrm{ESI}+) \mathrm{m} / \mathrm{z}: 316[\mathrm{M}+\mathrm{Na}]^{+}, 332[\mathrm{M}+\mathrm{K}]^{+} .{ }^{13} \mathrm{C}_{1}{ }^{1} \mathrm{H}\right\}-\mathrm{NMR}$ (75 MHz, $\left.\delta \mathrm{ppm} / \mathrm{CDCl}_{3}\right): 164.8(\mathrm{C}), 161.9(\mathrm{C}), 136.5(\mathrm{C}), 132.9(\mathrm{C}), 129.5(\mathrm{CH}), 129.5(\mathrm{CH}), 129.1(\mathrm{CH})$, $128.9(\mathrm{CH}), 128.7(\mathrm{CH}), 128.7(\mathrm{CH}), 128.3(\mathrm{CH}), 128.3(\mathrm{CH}), 128.0(\mathrm{CH}), 128.0(\mathrm{CH}), 127.6(\mathrm{CH}), 127.1(\mathrm{C})$, $108.1(\mathrm{C}), 90.3(\mathrm{CH}), 46.2\left(\mathrm{CH}_{2}\right), 46.1\left(\mathrm{CH}_{2}\right), 41.0\left(\mathrm{CH}_{2}\right), 36.3(\mathrm{C}), 29.9\left(\mathrm{CH}_{3}\right), 29.1\left(\mathrm{CH}_{3}\right) .{ }^{1} \mathrm{H}-\mathrm{NMR}$ $\left(300 \mathrm{MHz}, \delta \mathrm{ppm} / \mathrm{CDCl}_{3}\right): 7.58(\mathrm{dd}, J=1.7,7.3 \mathrm{~Hz}, 2 \mathrm{H}), 7.41-7.29(\mathrm{~m}, 7 \mathrm{H}), 6.62(\mathrm{~s}, 1 \mathrm{H}), 5.76(\mathrm{~s}, 1 \mathrm{H})$, $5.44(\mathrm{~d}, J=15.4 \mathrm{~Hz}, 1 \mathrm{H}), 3.99(\mathrm{~d}, J=15.4 \mathrm{~Hz}, 1 \mathrm{H}), 2.53-2.29(\mathrm{~m}, 5 \mathrm{H}), 1.19(\mathrm{~s}, 3 \mathrm{H}), 1.13(\mathrm{~s}, 3 \mathrm{H})$.

4f: Following the general procedure, the reaction between crotonaldehyde $(76 \mu \mathrm{L}, 0.91 \mathrm{mmol})$, furfurylamine ( $81 \mu \mathrm{L}, 0.91 \mathrm{mmol})$, and 5,5-dimethyl-2-diazo-cyclohexan-1,3-dione (152 mg, $0.91 \mathrm{mmol})$ at $140{ }^{\circ} \mathrm{C}$ for $15 \mathrm{~min}$ afforded the 1,3-oxazin-4-one $4 \mathrm{f}(53 \mathrm{mg}, 20 \%)$ as a colorless oil. $\mathrm{Rf}\left(\mathrm{Et}_{2} \mathrm{O} /\right.$ petroleum ether 2:8) $=0.41$. HRMS (ESI +$) m / z:[\mathrm{M}+\mathrm{H}]^{+}$calcd for $\mathrm{C}_{17} \mathrm{H}_{22} \mathrm{NO}_{3}{ }^{+}$288.1594, found 288.1591. ${ }^{13} \mathrm{C}\left\{{ }^{1} \mathrm{H}\right\}$-NMR $\left(75 \mathrm{MHz}, \delta \mathrm{ppm} / \mathrm{CDCl}_{3}\right): 165.9(\mathrm{C}), 162.5(\mathrm{C}), 151.0(\mathrm{C}), 142.0(\mathrm{CH}), 133.4(\mathrm{CH})$, 124.4 (CH), $110.3(\mathrm{CH}), 108.1(\mathrm{CH}), 107.9(\mathrm{C}), 89.7(\mathrm{CH}), 46.1\left(\mathrm{CH}_{2}\right), 41.1\left(\mathrm{CH}_{2}\right), 38.2\left(\mathrm{CH}_{2}\right), 36.2(\mathrm{C})$, $30.0\left(\mathrm{CH}_{3}\right), 29.9\left(\mathrm{CH}_{3}\right), 17.5\left(\mathrm{CH}_{3}\right) .{ }^{1} \mathrm{H}$ NMR $\left(300 \mathrm{MHz}, \delta \mathrm{ppm} / \mathrm{CDCl}_{3}\right)$ : 7.31-7.30 (m, $\left.1 \mathrm{H}\right), 6.28-6.20$ $(\mathrm{m}, 2 \mathrm{H}), 5.85-5.73(\mathrm{~m}, 2 \mathrm{H}), 5.56(\mathrm{~d}, J=6.4 \mathrm{~Hz}, 1 \mathrm{H}), 4.87(\mathrm{~d}, J=15.7 \mathrm{~Hz}, 1 \mathrm{H}), 4.18(\mathrm{~d}, J=15.7 \mathrm{~Hz}, 1 \mathrm{H})$, 2.37-2.27 (m, 4H), $1.73(\mathrm{~d}, J=6.4 \mathrm{~Hz}, 3 \mathrm{H}), 1.13(\mathrm{~s}, 3 \mathrm{H}), 1.12(\mathrm{~s}, 3 \mathrm{H})$. 
4g: Following the general procedure, the reaction between cinnamaldehyde $(126 \mu \mathrm{L}, 1.0 \mathrm{mmol})$, benzylamine $(109 \mu \mathrm{L}, 1.0 \mathrm{mmol})$, and 2-diazo-cycloheptan-1,3-dione (152 mg, $1.0 \mathrm{mmol})$ at $160{ }^{\circ} \mathrm{C}$ for $15 \mathrm{~min}$ afforded the 1,3-oxazin-4-one $\mathbf{4 g}$ (crude product that required no purification, $379 \mathrm{mg}$ with purity $>90 \%$ from the NMR analyses, quantitative) as a brown oil. HRMS (ESI+) $m / z:[\mathrm{M}+\mathrm{H}]^{+}$ calcd for $\mathrm{C}_{23} \mathrm{H}_{24} \mathrm{NO}_{2}{ }^{+} 346.1802$, found 346.1807. ${ }^{13} \mathrm{C}\left\{{ }^{1} \mathrm{H}\right\}-\mathrm{NMR}\left(75 \mathrm{MHz}, \delta \mathrm{ppm} / \mathrm{CDCl}_{3}\right): 163.2(\mathrm{C})$, $160.7(\mathrm{C}), 137.2(\mathrm{C}), 135.3(\mathrm{CH}), 134.7(\mathrm{C}), 128.2(\mathrm{CH}), 128.2(\mathrm{CH}), 128.2(\mathrm{CH}), 128.2(\mathrm{CH}), 127.8(\mathrm{CH})$, $127.4(\mathrm{CH}), 127.4(\mathrm{CH}), 126.9(\mathrm{CH}), 126.5(\mathrm{CH}), 126.5(\mathrm{CH}), 121.8(\mathrm{CH}), 106.5(\mathrm{C}), 86.8(\mathrm{CH}), 45.3\left(\mathrm{CH}_{2}\right)$, $26.9\left(\mathrm{CH}_{2}\right), 21.6\left(\mathrm{CH}_{2}\right), 21.5\left(\mathrm{CH}_{2}\right), 21.1\left(\mathrm{CH}_{2}\right) .{ }^{1} \mathrm{H}-\mathrm{NMR}\left(300 \mathrm{MHz}, \delta \mathrm{ppm} / \mathrm{CDCl}_{3}\right): 7.35-7.16(\mathrm{~m}, 10 \mathrm{H})$, $6.56(\mathrm{~d}, J=15.9 \mathrm{~Hz}, 1 \mathrm{H}), 6.31(\mathrm{dd}, J=7.5,15.9 \mathrm{~Hz}, 1 \mathrm{H}), 5.61(\mathrm{~d}, J=7.5 \mathrm{~Hz}, 1 \mathrm{H}), 5.11(\mathrm{~d}, J=15.5 \mathrm{~Hz}$, $1 \mathrm{H}), 4.25$ (d, J = $15.5 \mathrm{~Hz}, 1 \mathrm{H}), 2.45$ (br, 2H), 2.19 (br, 2H), 1.68 (br, 4H).

4h: Following the general procedure, the reaction between cinnamaldehyde $(126 \mu \mathrm{L}, 1.0 \mathrm{mmol})$, $n$-propylamine $(82 \mu \mathrm{L}, 1.0 \mathrm{mmol})$, and 2-diazo-acetylacetone $(126 \mathrm{mg}, 1.0 \mathrm{mmol})$ at $140{ }^{\circ} \mathrm{C}$ for $5 \mathrm{~min}$ afforded the 1,3-oxazin-4-one $4 \mathbf{h}(213 \mathrm{mg}$, 78\%) as an orange oil. Rf (EtOAc/petroleum ether 2:8) $=0.27$. MS (ESI+) m/z: $294[\mathrm{M}+\mathrm{Na}]{ }^{+} .{ }^{13} \mathrm{C}\left\{{ }^{1} \mathrm{H}\right\}-\mathrm{NMR}\left(75 \mathrm{MHz}, \delta \mathrm{ppm} / \mathrm{CDCl}_{3}\right): 163.5(\mathrm{C}), 158.0(\mathrm{C}), 135.0(\mathrm{CH})$, $135.0(\mathrm{CH}), 128.4(\mathrm{CH}), 128.4(\mathrm{CH}), 128.4(\mathrm{CH}), 126.7(\mathrm{CH}), 126.7(\mathrm{CH}), 122.7(\mathrm{CH}), 105.0(\mathrm{C}), 87.0(\mathrm{CH})$, $44.7\left(\mathrm{CH}_{2}\right), 21.5\left(\mathrm{CH}_{2}\right), 16.9\left(\mathrm{CH}_{3}\right), 11.1\left(\mathrm{CH}_{3}\right), 10.1\left(\mathrm{CH}_{3}\right) .{ }^{1} \mathrm{H}-\mathrm{NMR}\left(300 \mathrm{MHz}, \delta \mathrm{ppm} / \mathrm{CDCl}_{3}\right): 7.38-7.24$ $(\mathrm{m}, 5 \mathrm{H}), 6.63(\mathrm{~d}, J=15.9 \mathrm{~Hz}, 1 \mathrm{H}), 6.33(\mathrm{dd}, J=15.9,6.6 \mathrm{~Hz}, 1 \mathrm{H}), 5.54(\mathrm{~d}, J=6.6 \mathrm{~Hz}, 1 \mathrm{H}), 3.65(\mathrm{ddd}, J=$ 13.9, 7.7, 7.1 Hz, 1H), $2.96(\mathrm{ddd}, J=13.9,7.7,7.1 \mathrm{~Hz}, 1 \mathrm{H}), 1.87$ (s, 3H), $1.76(\mathrm{~s}, 3 \mathrm{H}), 1.62-1.49(\mathrm{~m}, 2 \mathrm{H})$, $0.86(\mathrm{t}, J=7.5 \mathrm{~Hz}, 3 \mathrm{H})$.

iso-3h: Following the general procedure, the reaction between cinnamaldehyde $(151 \mu \mathrm{L}, 1.2 \mathrm{mmol})$, $n$-propylamine $(98 \mu \mathrm{L}, 1.2 \mathrm{mmol})$, and 2-diazo-acetylacetone $(151 \mathrm{mg}, 1.2 \mathrm{mmol})$ at $200{ }^{\circ} \mathrm{C}$ for $15 \mathrm{~min}$ afforded the hydropyridin-2-one iso-3h $(123 \mathrm{mg}, 38 \%)$ as a yellow oil. Rf (EtOAc/pentane 1:10) =0.62. HRMS (ESI+) $m / z:[\mathrm{M}+\mathrm{H}]^{+}$calcd for $\mathrm{C}_{17} \mathrm{H}_{22} \mathrm{NO}_{2}{ }^{+} 272.1645$, found $272.1645 .{ }^{13} \mathrm{C}\left\{{ }^{1} \mathrm{H}\right\}-\mathrm{NMR}(101 \mathrm{MHz}$, $\left.\delta \mathrm{ppm} / \mathrm{CDCl}_{3}\right)$ : $208.1(\mathrm{C}), 170.0(\mathrm{C}), 138.4(\mathrm{C}), 129.3(\mathrm{CH}), 129.1(2 \mathrm{CH}), 128.9(2 \mathrm{CH}), 127.9(\mathrm{CH})$, $108.0(\mathrm{CH}), 59.7(\mathrm{C}), 50.4(\mathrm{CH}), 48.7\left(\mathrm{CH}_{2}\right), 30.0\left(\mathrm{CH}_{3}\right), 22.6\left(\mathrm{CH}_{3}\right), 22.0\left(\mathrm{CH}_{2}\right), 11.4,\left(\mathrm{CH}_{3}\right) .{ }^{1} \mathrm{H}-\mathrm{NMR}(400$ $\left.\mathrm{MHz}, \delta \mathrm{ppm} / \mathrm{CDCl}_{3}\right): 7.31-7.24(\mathrm{~m}, 3 \mathrm{H}), 7.15-7.13(\mathrm{~m}, 2 \mathrm{H}), 6.29(\mathrm{dd}, J=7.9,0.9 \mathrm{~Hz}, 1 \mathrm{H}), 5.28(\mathrm{dd}, J=8.0$, $5.2 \mathrm{~Hz}, 1 \mathrm{H}), 3.65-3.50(\mathrm{~m}, 2 \mathrm{H}), 3.46(\mathrm{~d}, J=5.2 \mathrm{~Hz}, 1 \mathrm{H}), 1.71(\mathrm{q}, J=7.5 \mathrm{~Hz}, 2 \mathrm{H}), 1.55(\mathrm{~s}, 3 \mathrm{H}), 1.50(\mathrm{~s}, 3 \mathrm{H})$, $1.0(\mathrm{t}, J=7.5 \mathrm{~Hz}, 3 \mathrm{H})$. The relative stereochemistry in iso-3h was determined by a NOESY experiment.

4i: Following the general procedure, the reaction between cinnamaldehyde $(126 \mu \mathrm{L}, 1.0 \mathrm{mmol})$, allylamine $(75 \mu \mathrm{L}, 1.0 \mathrm{mmol})$, and methyl 2-diazo-acetylacetate $(142 \mathrm{mg}, 1.0 \mathrm{mmol})$ at $160{ }^{\circ} \mathrm{C}$ for $5 \mathrm{~min}$ afforded the 1,3-oxazin-4-one $4 \mathbf{i}(124 \mathrm{mg}, 43 \%)$ as a yellow oil. Rf (EtOAc/petroleum ether 2:8) =0.37. MS (ESI+) m/z: $308[\mathrm{M}+\mathrm{Na}]{ }^{+} .{ }^{13} \mathrm{C}\left\{{ }^{1} \mathrm{H}\right\}-\mathrm{NMR}\left(75 \mathrm{MHz}, \delta \mathrm{ppm} / \mathrm{CDCl}_{3}\right): 170.6(\mathrm{C}), 167.9(\mathrm{C}), 139.0(\mathrm{C})$, $132.3(\mathrm{CH}), 128.7(\mathrm{CH}), 128.7(\mathrm{CH}), 128.6(\mathrm{CH}), 128.0(\mathrm{CH}), 128.0(\mathrm{CH}), 127.4(\mathrm{CH}), 117.5\left(\mathrm{CH}_{2}\right)$, $108.0(\mathrm{CH}), 54.7(\mathrm{C}), 51.6\left(\mathrm{CH}_{3}\right), 49.9(\mathrm{CH}), 48.7\left(\mathrm{CH}_{2}\right), 21.4\left(\mathrm{CH}_{3}\right) .{ }^{1} \mathrm{H}-\mathrm{NMR}\left(300 \mathrm{MHz}, \delta \mathrm{ppm} / \mathrm{CDCl}_{3}\right)$ : 7.32-7.15 (m, 3H), 7.14-7.09 (m, 2H), $6.22(\mathrm{dd}, J=7.8,2.2 \mathrm{~Hz}, 1 \mathrm{H}), 5.93-5.77(\mathrm{~m}, 1 \mathrm{H}), 5.33-5.21(\mathrm{~m}, 3 \mathrm{H})$, $4.26(\mathrm{dd}, J=15.3,5.6 \mathrm{~Hz}, 1 \mathrm{H}), 4,15(\mathrm{dd}, J=15.3,5.9 \mathrm{~Hz}, 1 \mathrm{H}), 3.66(\mathrm{dd}, J=3.8,2.1 \mathrm{~Hz}, 1 \mathrm{H}), 3.32(\mathrm{~s}, 3 \mathrm{H})$, $1.55(\mathrm{~s}, 3 \mathrm{H})$.

\section{Conclusions}

The formal aza-Diels-Alder cycloadditions of $\alpha$-oxoketenes with 1-azadienes were examined in detail. Two distinct pericyclic products were obtained experimentally: 1,3-oxazin-4-ones of type 4 when the $\alpha$-oxoketenes reacted as $4 \pi$ partners (1-oxadienes) with the $\mathrm{C}=\mathrm{N}$ bond of the 1 -azadienes as $2 \pi$ components, and hydropyridin-2-ones of type 3 when the 1-azadienes reacted as the $4 \pi$ partners with the $\mathrm{C}=\mathrm{C}$ bond of the ketene groups as the $2 \pi$ components. Generally, it was shown experimentally that 1,3-oxazin-4-ones 4 are the kinetic products, and that hydropyridin-2-ones 3 can be obtained from reactions conducted at higher temperature, indicating some degree of thermodynamic control. However, some small variations in the structure of the $\alpha$-oxoketenes or the 1 -azadienes have led to sharp differences in the periselectivity, as well as inversion of the diastereoselectivity with an acyclic $\alpha$-oxoketene. Computational modeling of these aza-Diels-Alder cycloadditions by DFT methods confirmed that the 1,3-oxazin-4-ones 4 are invariably the kinetic products, as well 
as that both diastereomers of hydropyridin-2-ones 3 are thermodynamically favored with, in all cases, the actual thermodynamic diastereomers computationally identified as iso-3. Experimentally, when possible, the reactions with cyclic $\alpha$-oxoketenes have led exclusively to hydropyridin-2-ones 3 , not their diastereomers iso-3. In these cases, the computational model allowed identifying that formation of the thermodynamic product iso- 3 is actually kinetically impeded under the examined reaction conditions, notably by the formation of the $\alpha$-oxoketenes cyclodimers. This situation is different for reactions with an acyclic $\alpha$-oxoketene, which led experimentally to the thermodynamic product iso-3. In this case, the model shows that formation of iso-3 is now kinetically allowed under the examined reaction conditions. This difference of behavior between cyclic and acyclic $\alpha$-oxoketenes results from the existence of the additional and more stable s-trans conformation in acyclic $\alpha$-oxoketenes. All in all, the factors governing periselectivity and diastereoselectivity in the aza-Diels-Alder cycloadditions of $\alpha$-oxoketenes with 1-azadienes have been fully identified by a combined experimental and theoretical approach.

Supplementary Materials: Details of the calculations and copies of the NMR spectra.

Author Contributions: M.P., J.R. and Y.C. conceived the study, designed the experiments, and analysed the data. M.P. and G.D. performed the synthetic chemistry and analysed the data. M.R., G.D. and Y.C. performed the computational work and analysed the data. Y.C. wrote the manuscript. All authors have read and agreed to the published version of the manuscript.

Funding: This research received no external specific funding.

Acknowledgments: Part of this work was supported by the computing facilities of the CRCMM, 'Centre Régional de Compétences en Modélisation Moléculaire de Marseille'. Financial support from Aix-Marseille University, Centrale Marseille and the CNRS is gratefully acknowledged. M.P. and G.D. thank the French government for doctoral studentships.

Conflicts of Interest: The authors declare no conflict of interest.

\section{References}

1. Wentrup, C.; Heilmayer, W.; Kollenz, G. $\alpha$-Oxoketenes-Preparation and Chemistry. Synthesis 1994, 1994, 1219-1248. [CrossRef]

2. Hyatt, J.A.; Raynolds, P.W. Ketene cycloadditions. In Organic Reactions; Paquette, L.A., Ed.; John Wiley \& Sons, Inc.: Hoboken, NJ, USA, 1994; Volume 45, pp. 159-635.

3. Kollenz, G.; Ebner, S. Acylketenes. In Science of Synthesis: Houben-Weyl Methods of Molecular Transformations; Danheiser, R., Ed.; Georg Thieme: Stuttgart, Germany, 2006; Volume 23, pp. 271-349.

4. Reber, K.P.; Tilley, S.D.; Sorensen, E.J. Bond formations by intermolecular and intramolecular trappings of acylketenes and their applications in natural product synthesis. Chem. Soc. Rev. 2009, 38, 3022-3034. [CrossRef] [PubMed]

5. Cookson, R.; Barrett, T.N.; Barrett, A.G.M. $\beta$-Keto-dioxinones and $\beta, \delta$-Diketo-dioxinones in Biomimetic Resorcylate Total Synthesis. Acc. Chem. Res. 2015, 48, 628-642. [CrossRef] [PubMed]

6. Ford, A.; Miel, H.; Ring, A.; Slattery, C.N.; Maguire, A.R.; McKervey, M.A. Modern Organic Synthesis with $\alpha$-Diazocarbonyl Compounds. Chem. Rev. 2015, 115, 9981-10080. [CrossRef] [PubMed]

7. Wolff, L. Ueber Diazoanhydride. Liebigs Ann. Chem. 1902, 325, 129-195. [CrossRef]

8. Presset, M.; Coquerel, Y.; Rodriguez, J. Microwave-Assisted Wolff Rearrangement of Cyclic 2-Diazo-1,3-Diketones: An Eco-compatible Route to $\alpha$-Carbonylated Cycloalkanones. J. Org. Chem. 2009, 74, 415-418. [CrossRef] [PubMed]

9. Kappe, C.O.; Evans, R.A.; Kennard, C.H.L.; Wentrup, C. Dipivaloylketene and Its Unusual Dimerization to a Permanently Stable $\alpha$-Oxoketene. J. Am. Chem. Soc. 1991, 113, 4234-4237. [CrossRef]

10. Kappe, C.O.; Färber, G.; Wentrup, C.; Kollenz, G. Dipivaloylketene and Its Dimers. [2 + 4] versus [2 + 2] Cycloaddition Reactions of $\alpha$-Oxo Ketenes. J. Org. Chem. 1992, 57, 7078-7083. [CrossRef]

11. Castillo, J.-C.; Castro Agudelo, B.; Gálvez, J.; Carissan, Y.; Rodriguez, J.; Coquerel, Y. Periselectivity in the aza-Diels-Alder Cycloaddition between $\alpha$-Oxoketenes and N-(5-Pyrazolyl)imines: A Combined Experimental and Theoretical Study. J. Org. Chem. 2020, 85, 7368-7377. [CrossRef] [PubMed] 
12. Hyatt, J.A.; Feldman, P.L.; Clemens, R.J. Ketenes. 20. Thermal decomposition of 2,2,6-trimethyl-4H-1,3-dioxin-4-one and 1-ethoxybutyn-3-one. Acetylketene. J. Org. Chem. 1984, 49, 5105-5108. [CrossRef]

13. Kirmse, W. 100 Years of the Wolff Rearrangement. Eur. J. Org. Chem. 2002, 2002, 2193-2256. [CrossRef]

14. Coquerel, Y.; Rodriguez, J. The Wolff rearrangement: Tactics, strategies and recent applications in organic synthesis. In Molecular Rearrangements in Organic Synthesis; Rojas, C., Ed.; Wiley: Hoboken, NJ, USA, 2015; Chapter 3, pp. 59-84.

15. Presset, M.; Coquerel, Y.; Rodriguez, J. Microwave-Assisted Domino and Multicomponent Reactions with Cyclic Acylketenes: Expeditious Syntheses of Oxazinones and Oxazindiones. J. Org. Lett. 2009, 11, 5706-5709. [CrossRef] [PubMed]

16. Presset, M.; Coquerel, Y.; Rodriguez, J. Periselectivity Switch of Acylketenes in Cycloadditions with 1-Azadienes: Microwave-Assisted Diastereoselective Domino Three-Component Synthesis of $\alpha$-Spiro- $\delta$-lactams. J. Org. Lett. 2010, 12, 4212-4215. [CrossRef] [PubMed]

17. Presset, M.; Mohanan, K.; Hamann, M.; Coquerel, Y.; Rodriguez, J. 1,3-Dipolar Cycloaddition of Hydrazones with $\alpha$-Oxo-ketenes: A Three-Component Stereoselective Entry to Pyrazolidinones and an Original Class of Spirooxindoles. J. Org. Lett. 2011, 13, 4124-4127. [CrossRef] [PubMed]

18. Presset, M.; Mailhol, D.; Coquerel, Y.; Rodriguez, J. Diazo-Transfer Reactions to 1,3-Dicarbonyl Compounds with Tosyl Azide. Synthesis 2011, 2549-2552. [CrossRef]

Sample Availability: Samples of the compounds are not available from the authors.

Publisher's Note: MDPI stays neutral with regard to jurisdictional claims in published maps and institutional affiliations.

(C) 2020 by the authors. Licensee MDPI, Basel, Switzerland. This article is an open access article distributed under the terms and conditions of the Creative Commons Attribution (CC BY) license (http://creativecommons.org/licenses/by/4.0/). 